\title{
SINGLE SUBJECT RULES AND THE LEGISLATIVE PROCESS
}

\author{
Michael D. Gilbert
}

\begin{abstract}
Despite generating thousands of cases on important public issues, the single subject rule remains a source of uncertainty and inconsistency. The root of the problem lies in the inability to define the term "subject" using legal doctrine. This paper reexamines the single subject rule through the lens of public choice theory and finds that its purposes are wrongheaded. Logrolling is not necessarily harmful, and improving political transparency requires legislative compromises to be packaged together rather than spread across multiple acts. Riding is not a form of logrolling but an analytically distinct and more threatening practice. This analysis yields a precise, political definition of "subject" and a new framework for resolving single subject disputes.
\end{abstract}

* Ph.D. candidate, Jurisprudence and Social Policy, University of California, Berkeley. J.D., School of Law, University of California, Berkeley (Boalt Hall), 2005. I owe primary thanks for inspiration and support to Robert Cooter. Thanks also to Anne Joseph, Max Stearns, Matt Stephenson, Adrian Vermeule, Barry Weingast, John Yoo, and other participants in the August 2005 Berkeley Workshop on Constitutional Law and Economics; and Brian Broughman, Malcolm Feeley, Philip Frickey, Rick Hasen, Robert Kagan, Josh Levine, Andrew Morriss, Lisa Schroeer, Martin Shapiro, Stefani Smith, and the Institute for Humane Studies. 
Table of Contents

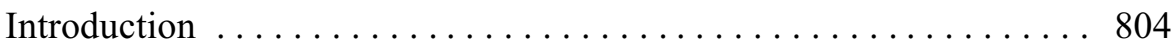

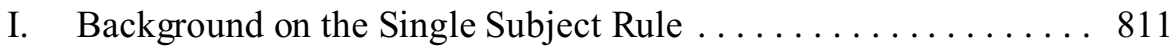

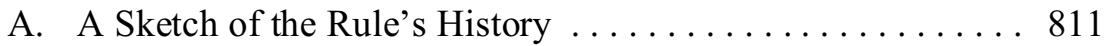

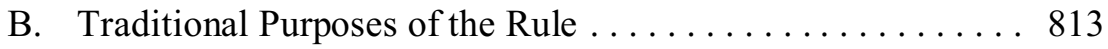

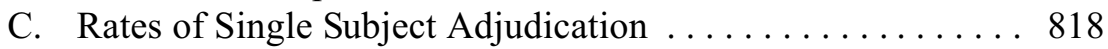

II. Problems in the Application of the Single Subject Rule . . . . . 823

A. Judicial Deference and the Appropriations Exception .... . 823

B. Defining a Single Subject: The Fumble for a Test . . . . . . 824

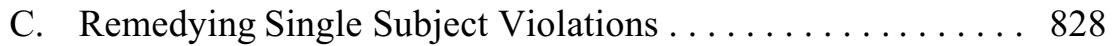

D. Summary: The State of Single Subject Jurisprudence . . . . 829

III. Reevaluating the Single Subject Rule in Light of Public

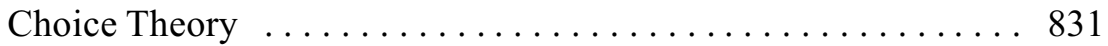

A. The Vexatious Worm Revisited: Logrolling and Cooperative Surplus . . . . . . . . . . . . . . . . . 831

B. Riders: Manipulations of the Legislative Process $\ldots \ldots \ldots 836$

C. Public Choice Theory and Political Transparency ....... 844

D. Gubernatorial Influence and Legislative Bargains . . . . . . 847

IV. A New Approach to Single Subject Adjudication . . . . . . . . . . 849

A. Courts Should Condone Logrolling ... . . . . . . . . . . 849

B. Courts Should Invalidate Bills Containing Riders . . . . . 858

C. Courts Must Enforce the Title Requirement . . . . . . . . 865

D. Judges Should Think Twice Before Severing Bills . . . . . 867

Conclusion ... . . . . . . . . . . . . . . . . . . . . . . . . . . . . . . . 869

\section{INTRODUCTION}

The indeterminacy of the term "subject," . . cannot be overcome by synonyms, paraphrases, and tautological formulas. It can either be replaced or supplemented by a formula that sets out some concrete goals or operational directives, or measures will be left to continual case-by-case decisions under standards so meaningless that it is difficult to avoid ad hoc ... reactions to the merits of individual measures."*

In October 2004, a state court in Louisiana invalidated a state constitutional amendment banning gay marriage less than three weeks after 
voters expressed overwhelming support for it on a statewide ballot. ${ }^{1}$ The court did not base its decision on substantive principles of equal protection or fundamental rights. ${ }^{2}$ Rather, its intrusion into social policy was justified by a procedural provision in the state constitution: the single subject rule. ${ }^{3}$ The rule requires the state legislature to confine all acts to a single subject. ${ }^{4}$ The purpose of the rule is to combat various forms of legislative misconduct. ${ }^{5}$ Louisiana's legislature designed the amendment to ban not only gay marriages but also civil unions, and the court found that these dual aims constituted separate subjects in violation of the rule. ${ }^{6}$ To underscore that the infirmity was purely procedural, the court made clear that separate amendments to ban gay marriage and civil unions would be constitutionally sound. ${ }^{7}$ Single subject challenges to anti-gay marriage laws have also been raised in Georgia and Kentucky, and similar litigation is anticipated in Arizona. ${ }^{8}$

These particular cases, though mostly unsuccessful, ${ }^{9}$ represent the latest in a string of high-profile attacks on legislation that rely on the single subject rule. In the last century-and-a-half, Louisiana's courts have dealt with over 300 single subject challenges to bills addressing everything from the definition of murder to jurisdiction over the state's Department of Environmental Quality. ${ }^{10}$ Together, courts in Georgia and Kentucky have resolved almost

1. See Forum for Equal. PAC v. McKeithen, 893 So. $2 \mathrm{~d} 715$ (La. 2005) (recounting the history of the district court case). Seventy-eight percent of voters supported the amendment. See id. at 718.

2. Id. at 720 .

3. Id.

4. See LA. Const. art. 3, § 15(A) ("Every bill, except the general appropriation bill and bills for the enactment, rearrangement, codification, or revision of a system of laws, shall be confined to one object."). The Louisiana Constitution is one of several to use the term "object" rather than "subject." In practice, there is no difference between these formulations. See Millard H. Ruud, No Law Shall Embrace More Than One Subject, 42 Minn. L. Rev. 389, 395 (1958).

5. See infra Part I.B.

6. See McKeithen, 893 So. $2 \mathrm{~d}$ at $721-22$.

7. Id. at 722; see Ed Anderson, Same-Sex Marriage Ban is Nullified, The Times-Picayune (New Orleans), Oct. 6, 2004, at 1.

8. See Perdue v. O'Kelley, 632 S.E.2d 110 (Ga. 2006); Wood v. Commonwealth ex rel. Grayson, Civ.A. 04-CI-01537, 2005 WL 1258921 (Ky. Cir. Ct., May 25, 2005); Chip Scutari, Democrat Joins High Court; Napolitano Ally Creates 3-2 Majority Among Arizona's Justices, The Ariz. Repu blic (Phoenix), June 15, 2005, at 1 A (reporting that the Arizona Supreme Court may soon face a single subject challenge to a proposed initiative that would ban same-sex marriage).

9. See McKeithen, 893 So. $2 \mathrm{~d}$ at 737 (overturning the Louisiana district court's decision); Perdue, 632 S.E.2d at 113 (holding that a state consitutional amendment banning gay marriage and civil unions does not contain multiple subjects); Wood, 2005 WL 1258921, at*7-8 (ruling that a state constitutional amendment to ban gay marriage does not violate Kentucky's single subject rule).

10. On the frequency of single subject litigation, see infra Part I.C. On the definition of murder, see State v. Cooper, 382 So. $2 d 963$ (La. 1980). On jurisdiction, see In re Matter of Rubicon, Inc., 670 So. 2d 
500 single subject disputes on matters ranging from tort liability to sexual offenses. ${ }^{11}$ Forty other states have some version of the single subject rule embedded in their constitutions, ${ }^{12}$ and collectively they have tried thousands of cases on a wide variety of topics. ${ }^{13}$

Many single subject cases have resulted in the invalidation of substantial and important legislation. In Simmons-Harris v. Goff, the Ohio Supreme Court struck down the state's school voucher program on single subject grounds. ${ }^{14}$ In Senate v. Jones, the California Supreme Court struck down a ballot initiative that would have transferred the power to reapportion political districts to the judiciary. ${ }^{15}$ In People v. Cervantes, the Illinois Supreme Court dismissed a gunrunning charge against a defendant because the underlying statute - the Safe Neighborhoods Law, which was intended to combat gangs, drugs, and other problems-violated the single subject rule and was invalidated. ${ }^{16}$ This decision led to a "nationally publicized furor in the Illinois legislature." ${ }^{17}$

Legal scholars have spilled much ink debating the merits of the single subject rule, ${ }^{18}$ and most agree that, despite its benign intent, it suffers from a

475 (La. Ct. App. 1996).

11. On the frequency of single subject litigation, see infra Part I.C. On tort liability, see Mullis v. S. Co. Servs., Inc., 296 S.E.2d 579 (Ga. 1982). On sexual offenses, see Martinez v. Commonwealth, 72 S.W.3d 581 (Ky. 2002).

12. See Brannon P. Denning \& Brooks R. Smith, Uneasy Riders: The Case for a Truth-inLegislation Amendment, 1999 Ut ah L. Rev. 957, 963; Martha J. Dragich, State Constitutional Restrictions on Legislative Procedure: Rethinking the Analysis of Original Purpose, Single Subject, and Clear Title Challenges, 38 HARV. J. on Legis. 103, 165-66 (2001). Neither of these authors mentions Mississippi's single subject rule for appropriations bills, which can be found in Article IV, § 69 of the Mississippi Constitution.

13. See infra Part I.C.

14. 711 N.E.2d 203 (Ohio 1999).

15. 988 P.2d 1089 (Cal. 1999).

16. 723 N.E.2d 265 (Ill. 1999).

17. Dragich, supra note 12, at 107.

18. Recent, helpful discussions of the application of the rule to legislation include: Denning \& Smith, supra note 12; Dragich, supra note 12; William N. Eskridge, JR., Phil IP P. Frickey \& Elizabeth Garrett, Legislation and Statutory Interpretation 173 (2000); M. Albert Figinski, Maryland's Constitutional One-Subject Rule: Neither A Dead Letter Nor An Undue Restriction, 27 U. BALt. L. Rev. 363 (1998); Stephanie Hoffer \& Travis McDade, Of Disunity and Logrolling: Ohio's One-Subject Rule and the Very Evils It Was Designed to Prevent, 51 Clev. St. L. Rev. 557 (2004); James Preston Schuck, Comment, Returning the "One" to Ohio's “One-Subject Rule”, 28 CAP. U. L. REV. 899 (2000).

Recent, helpful discussions of the rule in the context of initiatives include: Rachael Downey et al., A Survey of the Single Subject Rule as Applied to Statewide Initiatives, 13 J. ConteMP. LEgAL Issues 579 (2004); P.K. Jameson \& Marsha Hosack, Citizen Initiatives in Florida: An Analysis of Florida's Constitutional Initiative Process, Issues and Alternatives, 23 FLA. ST. U. L. Rev. 417 (1995); Kurt G. Kastorf, Comment, Logrolling Gets Logrolled: Same Sex Marriage, Direct Democracy, and the Single 
fundamental flaw: no one can define a "subject."19 Consequently, it is difficult to determine when a bill contains more than one. As a California Supreme Court Justice recently stated, "the term 'subject' is problematic ... . because almost any two legislative measures may be considered part of the same subject if that subject is defined with sufficient abstraction." 20 This has led to uncertainty among judges. Reading single subject opinions leaves no doubt that courts struggle with the rule.

Perhaps because of the rule's ambiguity, courts have been criticized for their handling of it. Judges have been accused of deciding single subject cases inconsistently, ${ }^{21}$ failing to explain the reasoning behind their decisions, ${ }^{22}$ permitting substantive legal considerations to influence procedural questions ${ }^{23}$ and imposing their personal beliefs under the guise of the rule's broad language. ${ }^{24}$ Relatedly, confusion surrounding the rule almost certainly leads to enforcement problems. Without clear guidelines for resolving single subject disputes, courts may uphold acts that deserve to be invalidated and strike down acts that should not be disturbed. Judges themselves recognize some of these problems. As a member of the Ohio Supreme Court recently exclaimed, "[t]his court continues to utilize the one-subject rule to invalidate legislation with little consistency or reason." 25

Judges, legislators, and society as a whole would benefit from a more coherent single subject jurisprudence. The volume of single subject litigation is substantial, and many of the cases involve laws addressing important public issues. Moreover, resolution of single subject disputes raises the classic

Subject Rule, 54 Emory L.J. 1633 (2005); Daniel H. Lowenstein, Initiatives and the New Single Subject Rule, 1 Election L.J. 35 (2002); Gerald F. Uelmen, Handling Hot Potatoes: Judicial Review of California Initiatives After Senate v. Jones, 41 SAnta Clara L. Rev. 999 (2001). Ruud provides the seminal discussion of single subject rules. See Ruud, supra note 4.

19. See, e.g., Richard Briffault, The Item Veto in State Courts, 66 Temp. L. Rev. 1171, 1177 (1993) ("The notion of a subject is inherently incapable of precise definition."); Courtney Paige Odishaw, Note, Curbing Legislative Chaos: Executive Choice or Congressional Responsibility?, 74 Iowa L. Rev. 227, 242 (1988) ("The main obstacle to the complete effectiveness of single subject restrictions . . . is the legislators' and courts' inability to define 'single subject' precisely.").

20. Manduley v. Superior Court, 41 P.3d 3, 37 (Cal. 2002) (Moreno, J., concurring) (citing Daniel H. Lowenstein, California Initiatives and the Single Subject Rule, 30 UCLA L. Rev. 936, 938-42 (1983)).

21. See, e.g., infra note 23 and accompanying text.

22. See, e.g., Denning \& Smith, supra note 12, at 995-96.

23. See, e.g., Lowenstein, supra note 18, at 40 (discussing the California Supreme Court's use of substantive principles of fairness to help decide a single subject case even though the rule is, in theory, purely procedural in nature).

24. See, e.g., id.

25. State ex rel. Ohio Civil Serv. Employees Ass'n v. State Employment Relations Bd., 818 N.E.2d 688, 706 (Ohio 2004) (Lundberg Stratton, J., dissenting). 
countermajoritarian difficulty. Unelected judges mustreview and strike down laws passed by a majority of representatives or, in the case of initiatives, private citizens. Finally, the salience of the rule has increased in recent years, as judges in many states have adopted a more aggressive stance towards single subject enforcement, striking down more laws and injecting themselves deeper into the legislative process. ${ }^{26}$ Taken together, these facts make clear that the single subject rule plays a momentous role in state constitutional law and policy. That the rule itself remains ill-defined and judicially unmanageable is troubling.

My aim in this paper is to re-conceive single subject jurisprudence, both by providing a precise definition of "subject" and by formulating a new judicial test for compliance with the rule. I will not try to delineate the contours of a "subject" by using legal doctrine, which is fruitless. ${ }^{27}$ Rather, I will scrutinize the single subject rule through the lens of politics. To that end, my work is grounded in public choice theory, the application of economic principles to political institutions. ${ }^{28}$ This approach permits progress where other, more doctrinal, takes on the single subject rule have failed.

I will begin by examining the traditional purposes of the rule. The single subject rule was designed to: (1) prevent "logrolling," the process of combining multiple proposals, some or all of which command only minority support, into an omnibus bill that will receive majority support; ${ }^{29}(2)$ eliminate "riders," unpopular provisions that are attached to otherwise popular bills; ${ }^{30}$ and (3) improve political transparency, both for citizens and politicians. ${ }^{31}$ I

26. See, e.g., Lowenstein, supra note 18, at 35 ("The recent change in judicial application of the single subject rule [to initiatives] has been dramatic. For better or for worse, critics who have called for more aggressive application of the ... rule are getting their way."); see also Dragich, supra note 12, at 107 (discussing recent, relatively strict application of the rule to legislation in Minnesota, Missouri, and Illinois); Hoffer \& McDade, supra note 18, at 558 (referring to Ohio's single subject rule as a "powerful arrow in the quiver of a supreme court increasingly willing to use it"); Kelly L. Bonanno, Case Note, City of Philadelphia v. Commonwealth: A Cynic's View of the Single-Subject Requirement and Germaneness Test, 14 WidENER L.J. 605 (2005) (discussing recent, relatively strict application of the rule to legislation in Pennsylvania).

27. On the difficulties in defining subjects based on legal doctrine alone, see infra Part II.B.

28. On public choice generally, see, e.g., Dennis C. Mueller, Public Choice III (2003).

29. See Ruud, supra note 4, at 391. Logrolling is usually understood to take place only between proposals that individually lack majority support. However, legislative roadblocks-including, for example, committee approvals and filibusters - can prevent even overwhelmingly popular bills from becoming law. To surmount those barriers, supporters of popular bills sometimes have to logroll. Although this paper focuses on logrolling among proposals that individually lack majority support, the analysis for all kinds of logrolling is the same.

30. See id.

31. See id.; Turnbull v. Fink, 668 A.2d 1370, 1383 (Del. 1995) (Holland, J., dissenting) (arguing 
will show that logrolling results from exchange; legislators trade votes to garner support for their favored provisions. This process always leaves a majority of legislators better off, though it may cause severe harm to a minority. In contrast, riders do not result from exchange but rather a manipulation of legislative procedures. Well-placed legislators can attach self-serving measures to otherwise popular bills, and they need not offer anything to the measures' opponents. Consequently, riding always leaves a majority of legislators worse off, though it may yield a significant benefit to a minority. Finally, I will explain that confining acts to a single subject can cut against political transparency. Rigidly separating bills can make it difficult to grasp the compromises that underpin legislation.

In light of this analysis, I will argue that the single subject rule should not be used to prevent logrolling. Logrolls can be socially beneficial or harmful, and courts cannot possibly filter one from the other on a case-by-case basis. Doing so would require more information than courts will ever possess. A better approach is to adopt a presumption for or against logrolling and apply it in every case. I will argue that logrolling tends to be beneficial and that judicial intervention in this area causes more harm than good.

In contrast to logrolling, riding should be eliminated under the auspices of the single subject rule. As with logrolls, riders can be socially beneficial or harmful, and courts cannot reliably distinguish one from the other. The solution to this problem is to adopt a presumption for or against riders and apply it consistently. I will argue that riding tends to be deleterious, and the presumption against it in single subject jurisprudence is appropriate.

To operationalize these concepts, I will develop a test that enables judges to distinguish logrolling from riding. In brief, the test instructs judges to parse a statute challenged on single subject grounds into its "functionally related" components. Courts must then ask the following question about each component: assuming all legislators adhere to their promises, if this component were removed and voted upon separately, would it receive majority support? If the answer is no, the component is a rider, and the bill violates the single subject rule. The basic insight is that independently popular measures and components of a logroll always command majority support. Therefore, they will always pass the test. Riders, on the other hand, never command majority support and will fail.

that a purpose of the single subject rule is to ensure that the content of bills is brought to the public's attention). 
The test further requires courts to consider whether the bill's title captures all of the issues that it touches upon. These considerations are captured by the following definition of a single subject: A bill can be said to embrace but one subject when all of its components command majority support due to their individual merits or legislative bargaining and the title gives notice of the bill's contents.

This analysis sheds new light on the purposes of the single subject rule and provides a clearer framework for approaching single subject disputes. This could significantly enhance the consistency and effectiveness of single subject adjudication and improve the legislative process and its outcomes. Granted, the test does not eliminate judicial discretion. Because courts lack perfect information about legislators' preferences, applying the test will still require some guesswork. But, as I will explain, courts can glean enough information in most cases to make educated guesses. Application of the test will not yield results that are more damaging and less predictable than what current single subject jurisprudence delivers.

In addition to lending structure to the single subject rule, this paper makes a separate contribution by developing an analytical distinction between logrolling and riding. Both processes are used to ensure passage of provisions that do not command majority support on their own merits. But whereas logrolling involves bargaining and compromise, riding stems from manipulations of the legislative process. The former always makes a majority of legislators better off, while the latter always makes a majority worse off. Existing analyses treat logrolling and riding as closely related or identical processes ${ }^{32}$ which is incorrect. This observation should be of interest to judges, legal scholars, and students of the legislative process more generally.

The paper will proceed in several steps. Part I reviews the rule's history and includes a discussion of its traditional purposes. It also presents empirical

32. See, e.g., Ruud, supra note 4, at 391 (riding "seems to be but a variation of logrolling"); Michael W. Catalano, The Single Subject Rule: A Check on Anti-Majoritarian Logrolling, 3 EMERGING Issues ST. CONST. L. 77, 79 (1990) (referring to riding as a "variation" of logrolling); see also EsKRIDGE, FRICKEY \& GARRETT, supra note 18, at 170-74 (discussing logrolling in the context of the single subject rule but not riding); Mueller, supra note 28 (presenting extensive analyses of logrolling but not riding). But see Lowenstein, supra note 20, at 958-63 (noting that logrolling moves a majority up its scale of preferences while riding moves a majority down its scale of preferences). As far as I can tell, Lowenstein is the only one who has recognized this distinction. Idevelop and expand this idea in Part III. Specifically, I show that logrolling results from exchange while riding results from manipulations of procedure. I also explain the circumstances under which riding can take place in legislatures (Lowenstein only analyzed the initiative process), I examine the welfare effects of riding, and I explore the incentives that riding can create for legislators. Finally, I reach a different conclusion from Lowenstein with respect to the implications of riding for single subject adjudication, and I articulate a test for distinguishing riders from logrolls. 
data on the rates of single subject adjudication over time and across states. Part II discusses courts' application of the rule. Courts apply a number of abstract and ineffective tests for determining whether a bill comprises more than one subject. Part III reexamines the purposes of the rule in light of public choice theory. The distinction between logrolling and riders is developed here. Part IV incorporates these insights and lays out a new approach for the resolution of single subject disputes.

Before continuing, I want to emphasize two points. First, this paper is concerned with the application of single subject rules to acts passed by state legislatures, not initiatives or other plebiscites. Some of the discussion in Part I applies to both contexts, but my analysis and recommendations in the rest of the paper are limited to the legislative scenario. ${ }^{33}$ Second, this paper does not address "separate vote" requirements for state constitutional amendments. ${ }^{34}$ Although such requirements are related to the single subject rule, I do not discuss them.

\section{Background on the Single Subject Rule}

\section{A. A Sketch of the Rule's History}

The single subject rule can be traced to ancient Rome, where crafty lawmakers learned to carry an unpopular provision by "harnessing it up with one more favored." ${ }^{35}$ To prevent this nefarious practice, the Romans in 98 B.C. forbade laws consisting of unrelated provisions. ${ }^{36}$ Similar legislative misbehavior plagued colonial America. In 1695, the Committee of the Privy Council complained that diverse acts in Massachusetts were "joined together under ye same title," making it difficult to vacate unpopular provisions without also invalidating favorable ones. ${ }^{37}$ In 1702, Queen Anne tried to check this practice, instructing Lord Cornbury of New Jersey to avoid "intermixing in one and the same Act ... such things as have no proper relation to each other." ${ }^{38}$

33. The application of single subject rules to initiatives and referenda is addressed in a work-inprogress. See Robert D. Cooter \& Michael D. Gilbert, A Theory of Democracy and the Single Subject Rule (Aug. 22, 2006) (unpublished manuscript, on file with author).

34. See Lowenstein, supra note 18, at 36-38.

35. Robert Luce, Legislative Procedure 548 (1922).

36. Id.

37. See id. at 549 (citing E.I. Miller, The Legislature of the Province of Virginia 111-12 (1907)) (internal quotations omitted).

38. Robert F. Williams, The New Jersey State Constitution: A Reference Guide 75 (1990) 
In 1818 , a single subject requirement for bills pertaining to government salaries materialized in the Illinois Constitution. ${ }^{39}$ The first general single subject rule appeared in New Jersey in 1844, followed by Louisiana and Texas in 1845 , and New York and Iowa in $1846 .^{40}$ By 1959 , some version of the rule had been adopted in forty-three states. ${ }^{41}$ The provision in the Nebraska Constitution is typical: "No bill shall contain more than one subject, and the subject shall be clearly expressed in the title." ${ }^{.2}$

As this quotation suggests, single subject rules almost universally include a title provision. ${ }^{43}$ This requirement has independent historical roots, making its inaugural appearance in the Georgia Constitution after the 1795 "Yazoo Land Fraud." ${ }^{44}$ Members of the Georgia legislature passed a bill—-titled "An Act for the Payment of the late State Troops" $"$ - that transferred vast tracts of public land to private companies. ${ }^{46}$ Many politicians profited from the act, ${ }^{47}$ which was "smuggled through the legislature under an innocent and deceptive title." ${ }^{48}$ Thereafter, General James Jackson demanded that each bill contain a title that adequately expressed its contents, and a provision to that effect was added to the Constitution in $1798 .^{49}$ Many other states adopted similar provisions. $^{50}$

(internal citation omitted). Very similar language was enshrined in New Jersey's constitution in 1844. See N.J. Const. art. IV, § 7, p. 4 ("To avoid improper influences which may result from intermixing in one and the same act such things as have no proper relation to each other, every law shall embrace but one object ....").

39. See Ruud, supra note 4, at 389.

40. See infra Part I.C. fig.2.

41. The single subject rules in Arkansas and Mississippi apply only to appropriations bills. See infra Part I.C. fig.2. The seven states without any single subject rule are Connecticut, Maine, Massachusetts, New Hampshire, North Carolina, Rhode Island, and Vermont. See infra Part I.C. fig.2. Recently, New Hampshire courts took steps towards adopting the single subject rule through common law. See Handley v. Town of Hooksett, 785 A.2d 399 (N.H. 2001) (addressing on the merits an alleged violation of the single subject rule without considering whether there was constitutional or statutory authority for its application); Tefft v. Bedford Sch. Dist., No. 03-E-394, 2003 WL 22254706, at *2 (N.H. Super. Ct. Sept. 25, 2003) ("I find it unnecessary to decide whether Handley presages that the single subject rule may have become part of the common law of New Hampshire ....").

42. NeB. Const. art. III, § 14.

43. Of the 43 states with some form of single subject rule, 40 also have a title provision. See Denning \& Smith, supra note 12, at app. A. Arkansas, Illinois, and Indiana do not. Id.

44. See id. at 966.

45. LuCE, supra note 35 , at 546.

46. See Denning \& Smith, supra note 12, at 966.

47. Id.

48. See Ruud, supra note 4, at 392.

49. See id.

50. See supra text accompanying note 41 . 


\section{B. Traditional Purposes of the Rule}

Judicial discussions of the subject and title requirements often fail to identify their respective purposes. ${ }^{51}$ Indeed, the rationales for them are usually combined:

The object of [the subject and title] provisions is summarized in the New Jersey provision itself: "To avoid improper influences which may result from intermixing in one and the same act such things as have no proper relation to each other." Other states cited omnibus bills that roll wide varieties of legislation into one act, logrolling, hodgepodge legislation, bills with low visibility and deceptive wording that skulk through the legislative process, and eleventh hour consideration of legislation as examples of the mischief that the single subject provisions were intended to halt..$^{52}$

From this checklist of apparently nefarious practices, three principal purposes of the single subject and title requirements can be distilled: (1) to prevent logrolling, (2) to prevent riding, and (3) to improve political transparency, both for citizens and their representatives. A fourth purpose, (4) to protect governors' veto power, has been developed in case law and bears mentioning. ${ }^{53}$

These purposes will be described in turn, as will the rationale for adopting a single subject rule to achieve them.

\section{Logrolling Is the Principal Evil That Single Subject Rules Seek to Check}

In his seminal examination of single subject provisions, Millard Ruud stated that the "primary and universally recognized purpose of the one-subject rule is to prevent logrolling." 54 There is some evidence that Ruud overstated his case but, for now, I will assume it to be true. ${ }^{55}$ Logrolling occurs when separate propositions, at least some of which command minority support, are

51. See Ruud, supra note 4, at 392.

52. Denning \& Smith, supra note 12, at 967 (internal citations omitted).

53. See, e.g., Johnson v. Walters, 819 P.2d 694 (Okla. 1991); Deborah S. Bartell, Note, The Interplay Between the Gubernatorial Veto and the One-Subject Rule in Oklahoma, 19 Окца. Сіту U. L. Rev. 273 (1994); Jeffrey Gray Knowles, Note, Enforcing the One-Subject Rule: The Case for a Subject Veto, 38 Hastings L.J. 563 (1987).

54. Ruud, supra note 4, at 391 . For opinions that cite eliminating logrolling as the main purpose of the single subject rule, see, e.g., Heggs v. State, 759 So. 2d 620, 627 (Fla. 2000); Johnson, 819 P.2d at 697; Litchfield Elementary Sch. Dist. v. Babbitt, 608 P.2d 792, 800-01 (Ariz. Ct. App. 1980).

55. See infra note 230 . 
combined into one bill that commands majority support. ${ }^{56}$ The situation could run as follows: Propositions A, B, and C are unpopular; each favors a special interest and is supported by separate blocks of politicians, each of which comprises 20 percent of the legislature. Standing alone, none of these provisions could become law. When combined into a single bill, however, the propositions could garner the support of 60 percent of the legislature. ${ }^{57}$ Although neither A nor B nor $\mathrm{C}$ has majority backing, all three become law.

In this situation, the legislators have effectively traded votes. ${ }^{58}$ In combining the propositions, those who support A have agreed-tacitly or explicitly - to vote for B and C so long as those supporting B and C vote for A. Vote trading of this sort need not take place in a single, combined bill. Supporters of B and C could agree to vote for $\mathrm{A}$ as a standalone measure as long as A's supporters vote for B and C when the time comes. Of course, vote trading across multiple bills is less likely to succeed. The second bill may never be brought to a vote, or A's supporters may decide to defect once their program has been enacted. ${ }^{59}$ Thus, legislators have an incentive to logroll their favored provisions into a single bill.

As this discussion suggests, courts fear logrolling because it threatens to give legal force to proposals that individually command only minority support. Thus, logrolling has been described as a "perversion of majority rule" ${ }^{90}$ that is "pernicious" and akin to "stealth and fraud in legislation." complaint about logrolling is that it requires legislators to decide on two or more issues with one vote. As the Supreme Court of Florida put it, logrolling can force legislators "to accept a repugnant provision in order to achieve adoption of a desired one." ${ }^{93}$

56. See Ruud, supra note 4, at 391; see also BlacK's Law Dictionary 953 (7th ed. 1999). But see supra note 29 (noting that logrolling can take place among provisions that have majority support).

57. This illustration assumes that the legislators who favor $A$ are not so opposed to $B$ and $C$ that they would vote against a bill that rolls all three proposals into one. The same assumption applies to legislators favoring B and C, respectively. I also assume that propositions A, B, and C are not complementary such that when combined their substance is different or of greater value than when separated (e.g., a spending measure and a tax measure, both of which look irresponsible if proposed alone but sensible if proposed together).

58. See Richard L. Hasen, Vote Buying, 88 CAL. L. REv. 1323, 1339 (2000) (noting that logrolling is "functionally equivalent to vote buying").

59. See ESKRIDGE, Frickey \& GARRETt, supra note 18, at 170 .

60. Ruud, supra note 4, at 399.

61. Burrell v. Miss. State Tax Comm'n, 536 So. 2 d 848, 865 (Miss. 1988) (Hawkins, J., dissenting) (citing Kerby v. Luhrs, 36 P.2d 549 (Ariz. 1934)).

62. State ex rel. Dix v. Celeste, 464 N.E.2d 153, 157 (Ohio 1984).

63. Dep't of Educ. v. Lewis, 416 So. $2 d$ 455, 459 (Fla. 1982). The same language could be used to describe the problem with legislative riders. See infra Part I.B.2. 
The single subject rule attempts to check logrolling by forbidding unnatural combinations of proposals in acts. The theory is that unrelated combinations could only be the product of logrolling. ${ }^{64}$ At least one commentator believes the rule has been ineffective. In a colorful attack, Justice Yetka of the Minnesota Supreme Court referred to logrolling as a "worm that was merely vexatious in the 19th century [but] has become a monster eating the constitution in the 20th." ${ }^{65}$

\section{Preventing Riding Is Another Goal of Single Subject Provisions}

A second purpose of the single subject rule is to prevent riders from being attached "to bills that are [so] popular . . . that the rider will secure adoption not on its own merits, but on the merits of the measure to which it is attached." ${ }^{\circ 6}$ The situation could unfold as follows: A popular provision, A, will command 80 percent support when it is brought to a general vote. Recognizing this fact, the committee proposing the bill attaches to it an unpopular rider, $\mathrm{B}$, which favors special interests. The combined bill, AB, is then submitted to the floor of the legislature. Depending on the rules of procedure, the full legislature may not be able to amend the bill. ${ }^{67}$ Or even if they could amend the bill, legislators may choose not to because other important bills are in the queue, making the opportunity costs of haggling too high. Thus, despite B's unpopularity, the bill passes, possibly with much less than 80 percent of the vote.

Riding is often conceptualized as a special type of logrolling. ${ }^{68}$ Insofar as both logrolling and riding require legislators to decide two or more issues with just one vote, this comparison is apt. However, the processes that give rise to logrolling and riding are different. As discussed, logrolling results from legislative bargaining. Minority blocks agree, directly or implicitly, to vote for one another's proposals in exchange for support on the issues each holds most dear. Riding, on the other hand, does not result from legislative bargains but rather manipulations of committee power and procedural rules. ${ }^{69}$

64. See, e.g., State ex rel. Ohio Acad. of Trial Lawyers v. Sheward, 715 N.E.2d 1062, 1098 (Ohio 1999) ("The one-subject provision attacks logrolling by disallowing unnatural combinations of provisions in acts ... on the theory that the best explanation for the unnatural combination is a tactical one-logrolling.").

65. State ex rel. Mattson v. Kiedrowski, 391 N.W.2d 777, 784 (Minn. 1986) (Yetka, J., concurring).

66. Ruud, supra note 4, at 391.

67. See infra Part III.B.

68. See supra notes 29-30 and accompanying text.

69. But see infra note 169 . 
The "sponsor of a rider only [has] to convince a few members of a committee or even the chairman of a committee to add the rider[,] and then it [can] ride through the legislative process on a popular bill." ${ }^{\text {70 }}$ Part III explores this distinction in depth.

Notwithstanding these different processes, judges find the results of riding and logrolling equally undesirable. "[E]ngrafting, upon subjects of great public benefit and importance, for local or selfish purposes, foreign and often pernicious matters" forces legislators to vote for provisions which, if "offered as independent subjects, would never have received [majority] support.","11

The single subject rule attempts to curb riding by striking down bills that contain multiple subjects. The theory is that at least one provision in a multisubject bill represents a rider. ${ }^{72}$

\section{Single Subject Requirements Aim to Improve Political Transparency}

A third purpose of the single subject rule is to simplify the lawmaking process, allowing both legislators and citizens to fully comprehend the intentions and ramifications of legislation. For legislators, limiting bills to one subject should enable them to scrutinize proposals without being distracted by extraneous matters. ${ }^{73}$ For citizens, limiting the scope of bills ensures that the public is afforded reasonable notice of the contents of legislation. ${ }^{74}$

The title requirement embedded in most single subject rules plays a prominent role in enhancing transparency. ${ }^{75}$ "The notion that members of . . state legislatures sit down and read, much less reread the text of the bills on which they vote is plainly erroneous...." ${ }^{, 76}$ Similarly, voters tend not to seek out much information on proposals that may become law. ${ }^{77}$ Legislators and

70. Catalano, supra note 32, at 79.

71. Porten Sullivan Corp. v. State, 568 A.2d 1111, 1117-18 (Md. 1990).

72. $C f$. id. (noting that a purpose of the rule is to prevent riding and then citing several opinions that imply that limiting bills to a single subject achieves this purpose).

73. See Ruud, supra note 4, at 391; see also, e.g., Wass v. Anderson, 252 N.W.2d 131, 135 (Minn. 1977) (limiting bills to a single subject allows legislators to "secure to every distinct measure of legislation a separate consideration and decision" (citing State v. Cassidy, 22 Minn. 312, 322 (1875))).

74. See Harbor v. Deukmejian, 742 P.2d 1290, 1300 (Cal. 1987).

75. See Ruud, supra note 4, at 392 ("The primary purpose of the title requirement is to prevent surprise and fraud upon the people and the legislature.").

76. Lowenstein, supra note 18 , at 46.

77. See id. 
citizens may, however, at least read the titles of bills. Ensuring that titles accurately reflect the content of bills should help prevent unwanted laws from slipping through the legislature. ${ }^{78}$

The title provision plays an important but less direct role in assisting courts to identify logrolling and riding. For example, the use of an excessively general title suggests that the bill embraces multiple subjects and may be the product of logrolling. ${ }^{79}$

\section{Single Subject Rules Can Be Used to Protect the Gubernatorial Veto Power}

A final and still-emerging purpose of the single subject rule is to prevent legislatures from eroding governors' veto power. ${ }^{80}$ Logrolling disparate provisions into one bill can force a governor to choose between enacting some provisions she dislikes and vetoing the entire bill, including components she favors. ${ }^{81}$ Similarly, attaching a rider to an otherwise popular bill can effectively "veto-proof[ ]" that rider. ${ }^{82}$ The relationship between the single subject rule and the veto was not explicitly recognized in early commentary. "Nevertheless, it cannot be denied that . . . the broader the definition ascribed to the term 'one subject' ... the more circumscribed is the Governor's power to veto legislation." 83

Forty-three state governors can exercise a line-item veto ${ }^{84}$ and this permits removal of some logrolled provisions and riders. But in 42 of these states, the line-item authority is limited to appropriations bills. ${ }^{85}$ Thus, there are substantial swaths of legislation that are vulnerable to these problems.

78. See Turnbull v. Fink, 668 A.2d 1370, 1383 (Oct. 1995) (Holland, J., dissenting).

79. Cf. Carl H. Manson, The Drafting of Statute Titles, 10 IND. L.J. 155, 162 (1934-35) ("Surplusage of body is present [when the body of a statute contains] material which is not expressed in the title and which is not germane to the other body material.... If the body contains two objects and the title contains only one of them, without question the one not expressed in the title is invalid.").

80. See Colo. Criminal Justice Reform Coal. v. Ortiz, 121 P.3d 288, 291 (Colo. Ct. App. 2005) (noting that one of the purposes of the Colorado constitutional single subject rule is "to enable the governor to consider each single subject of legislation separately in determining whether to exercise the veto power").

81. See Knowles, supra note 53, at 567-58.

82. See id.

83. Harbor v. Deukmejian, 742 P.2d 1290, 1299 (Cal. 1987).

84. Briffault, supra note 19 , at 1175 . Of these 43,41 have a single subject rule; only Indiana and Nevada have a single subject rule but no line-item veto. $1175-76$

85. Only Washington grants its governor a line-item veto applicable to all legislation. See id. at 
By limiting the scope of bills, the single subject rule allows governors to exercise their veto power with respect to each general provision that receives majority support in the legislature. This not only discourages logrolling and riding but also appears to boost governors' power by giving them more opportunities to exercise their authority. I will discuss this in depth in Part III.

\section{Rates of Single Subject Adjudication}

Having discussed the history and purposes of the single subject rule, I will now consider the frequency with which it is invoked. Most scholars who have addressed the rule believe it is a source of much litigation. Ruud, for example, stated that courts have been called on to resolve single subject disputes in "literally hundreds of cases." precise and astonishing assertion, claiming that state statutes had been struck down on single subject grounds more than 450 times ${ }^{87}$ In 1912, John Lapp stated that "[n]o question is raised so often in court as this one: Does the law have more than one subject and is that expressed in the title?" 88 Unfortunately, these scholars did not provide support for their claims.

Obtaining a record of single subject adjudication would be valuable in several regards. For one, it would indicate whether litigation rates are as high as these scholars claim. Indeed, my reexamination of the single subject rule is unmerited if the rule is never used. More generally, such a record would illuminate a portion of the legal landscape and offer clues about the dynamic relationship between the legislative and judicial branches.

I have compiled such a record. Incorporating the states' varying constitutional language, I devised a Westlaw search that I believe captures the vast majority of cases involving single subject issues. ${ }^{89}$ I then ran that search for every state with a single subject rule and recorded the number of hits. I also ran the search in a database containing all federal cases, on the theory that (1920).

86. Ruud, supra note 4 , at 403.

87. W.F. Dodd, The Problem of State Constitutional Construction, 20 Colum. L. Rev. 635, 640

88. John A. Lapp, The Initiative, Referendum and Recall, 43 Annals Am. Acad. Pol. \& Soc. Sci. 49,60 (1912).

89. I structured the general search as follows: ("single subject" or "single object" or "one subject" or "one object" +1 rule or requirement or provision or clause or limitation or doctrine) or "title-object clause" or (embrac! or relat! or refer! or contain! or confin!) /5 ("single subject" or "single object" or "one subject" or "one object"). I then tailored the search to each state by deleting all roots in the italicized phrase except for the one(s) that appear in that state's constitution. In some states, the constitutional language of the single subject rule has changed over time. I adjusted the searches accordingly. 
some single subject litigation has taken place in federal courts. ${ }^{90}$ The aggregate results are presented in Figures 1 and 2.

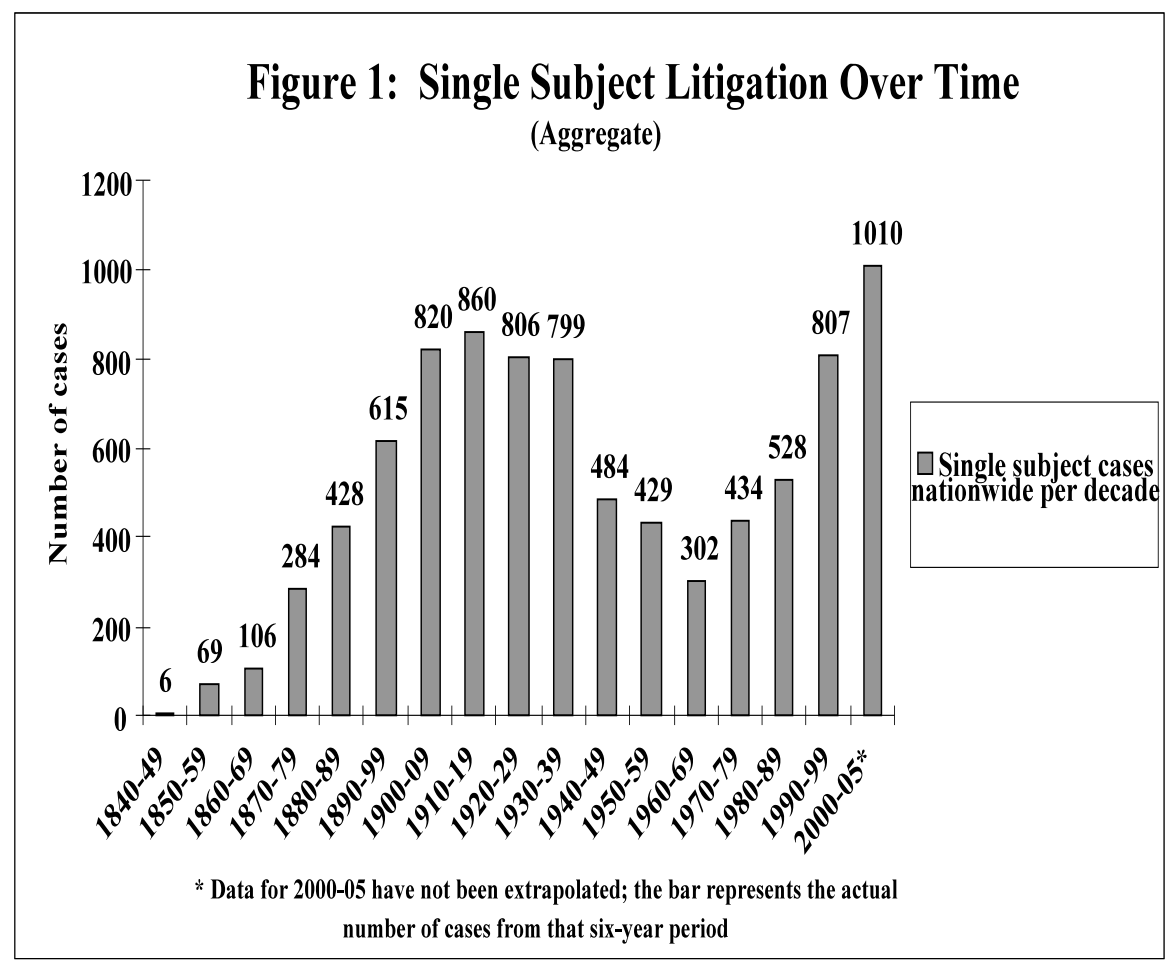

Several caveats are in order. The search is capturing cases in which single subject arguments were raised by the litigants but not actually ruled upon by the court. It also returns cases in which the relevant constitutional language was cited but the single subject rule was not actually at issue. In addition, the search is double counting single subject disputes that were litigated in front of both an appellate court and a supreme court. Finally, it is identifying single subject cases involving regular legislation as well as initiatives. This latter point helps to account for the recent, dramatic rise in single subject litigation, as courts in California, Oregon, and elsewhere have

90. Because a given federal court can hear cases involving the laws of many states, I could not target the federal search as carefully as the state searches. I had to use the full search phrase as described supra note 89 . 
begun to aggressively review initiatives for compliance with the rule. ${ }^{91}$ For all of these reasons, the search is overinclusive.

Countering these factors that inflate the results are two reasons to think that the search underestimates the actual amount of single subject litigation. First, courts may settle some single subject disputes without using the characteristic language that the search is designed to identify. Second, and more significantly, the search is not capturing single subject cases that were resolved at the state trial court level. Opinions generally are not issued in such cases, and consequently they are not in the Westlaw database.

Notwithstanding the roughness of the figures, ${ }^{92}$ early assertions about the frequency of single subject litigation appear to be accurate. By my count, 8,787 cases $^{93}$ have been litigated since New Jersey first adopted the rule, including 535 cases at the federal level. ${ }^{94}$ The litigation rates have varied dramatically over time. In the period from 1910 to 1919 , during which 41 states had single subject rules in place, ${ }^{95}$ over 800 cases were tried. In the 1960 s, during which all 43 single subject rules were in place, ${ }^{96}$ only 302 cases were tried. During the six years from 2000 to 2005, an astonishing 1,010 cases were litigated. That means an average of about three single subject cases have been adjudicated in the United States each week for the last six years.

In addition to varying over time, the frequency of single subject adjudication diverges across states. Courts in Nebraska have resolved 201 single subject disputes, while their neighbors in South Dakota have addressed only 80 . Virginia courts have adjudicated 76 cases, while Kentucky courts have resolved 245. In Florida, the figure is 906. Figure 2 presents the total

91. See supra note 26 . By my count, approximately 105 single subject cases litigated between 2001 and 2005 related to laws passed through direct democratic processes.

92. To test the accuracy of my search, I read all of the cases that it returned (through February 2004) for three states: Nevada, South Carolina, and Utah. Across those states, the search returned 248 cases. In most of those, the single subject rule was, in fact, at issue. In 210 of them, the court ruled on the single subject question. The success rate for single subject challenges was $22 \%$ in Nevada, $14 \%$ in South Carolina, and $7 \%$ in Utah.

93. Not all of these are cases in the technical sense. Some are advisory opinions. See, e.g., Advisory Opinion to the Att'y Gen. Re the Med. Liab. Claimant's Comp. Amend., 880 So. 2 d 675 (Fla. 2004) (per curiam).

94. Of these 535 search returns, fifty-seven are from the U.S. Supreme Court. To test the accuracy of the search at the federal level, I examined these cases. Forty-seven of them are on point.

95. Thirty-nine states adopted the single subject rule before 1910. New Mexico and Arizona adopted their rules in 1912. Alaska and Hawaii adopted the rule in 1959. See infra Part I.C. fig.2.

96. See infra Part I.C. fig.2. 
number of single subject cases that have been adjudicated in each state and in the federal courts. It also lists the year in which each state adopted the rule. ${ }^{97}$

I leave the exploration of litigation trends for another day. For present purposes, it is sufficient to point out that single subject litigation is, in fact, frequent, at least in an absolute sense. ${ }^{98}$ Courts are often called upon to determine whether a given bill or plebiscite violates the rule. In recent years, single subject litigation has blossomed. This flurry of activity makes a reexamination of the rule especially timely.

97. This information is drawn from Denning \& Smith, supra note 12, at 1024, with the following corrections: California adopted the rule in 1850, the year of statehood (I ignore single subject rules that may have existed pre-statehood in California or elsewhere). See, e.g., 50states.com, http://www.50 states .com/statehood.htm (last visited Mar. 6, 2006). Kansas adopted the rule in 1861, the year of statehood. See id. Minnesota adopted the rule in 1858, the year of statehood. See id. New Mexico adopted the rule in 1912, the year of statehood. See id. Utah adopted the rule in 1896, the year of statehood. See id. Arkansas adopted a general single subject rule in 1868 and then replaced it with a rule applying only to appropriations in 1874. See Laprairie v. City of Hot Springs, 187 S.W. 442, 443 (Ark. 1916). Georgia adopted the rule in 1861. See Bd. of Pub. Educ. for the City of Americus v. Barlow, 49 Ga. 232, 241 (1873). Illinois adopted a general single subject rule in 1848. See People ex rel. Chittenden v. Mellen, 32 Ill. 181, 182 (1863). Iowa adopted the rule in 1846. See State ex rel. Weir v. County Judge of Davis County, 2 Clarke 280, 282 (Iowa 1855) (noting that acts passed in the legislative session of 1846 were the first following the adoption of the rule). Kentucky apparently adopted the rule in 1850. See Chiles v. Drake, 59 Ky. (2 Met.) 146, 149-50 (1859) (making clear that the rule applied to legislation passed as early as 1854); Kentucky Legislature, Kentucky Constitution, http://www.lrc.ky.gov/Legresou/Constitu/intro.htm (last visited Mar. 6, 2006) (making clear on the Kentucky legislature's homepage that the state constitution in force at that time was established in 1850). Maryland adopted the rule in 1851. See Figinski, supra note 18, at 364. Mississippi adopted the rule for appropriations in 1890. See Barbour v. Delta Corr. Facility Auth., 871 So. 2d 703, 706-07 (Miss. 2004). Missouri adopted the rule in 1865. See In re Goode, 3 Mo. App. 226, 230 (1877). Nebraska adopted the rule in 1867. See White v. City of Lincoln, 5 Neb. 505, 515 (1877). Pennsylvania adopted the rule in 1864. See Blood v. Mercelliott, 53 Pa. 391, 393 (1867). South Carolina adopted the rule in 1865. See Dabney, Morgan \& Co. v. Bank of South Carolina, 3 S.C. 124, 138 (1871). Virginia adopted the rule in 1852. See Crawford v. Halsted, 61 Va. (20 Gratt.) 211, 219 (1871). West Virginia adopted the rule in 1863. See Shields v. Bennett, 8 W. Va. 74, 83-84 (1874).

98. The figures presented are in raw form; they do not account for changes in the rates of legislation. Per unit of legislation, single subject litigation could theoretically be declining. Regardless, the actual number of cases that courts must deal with is large and rising. 


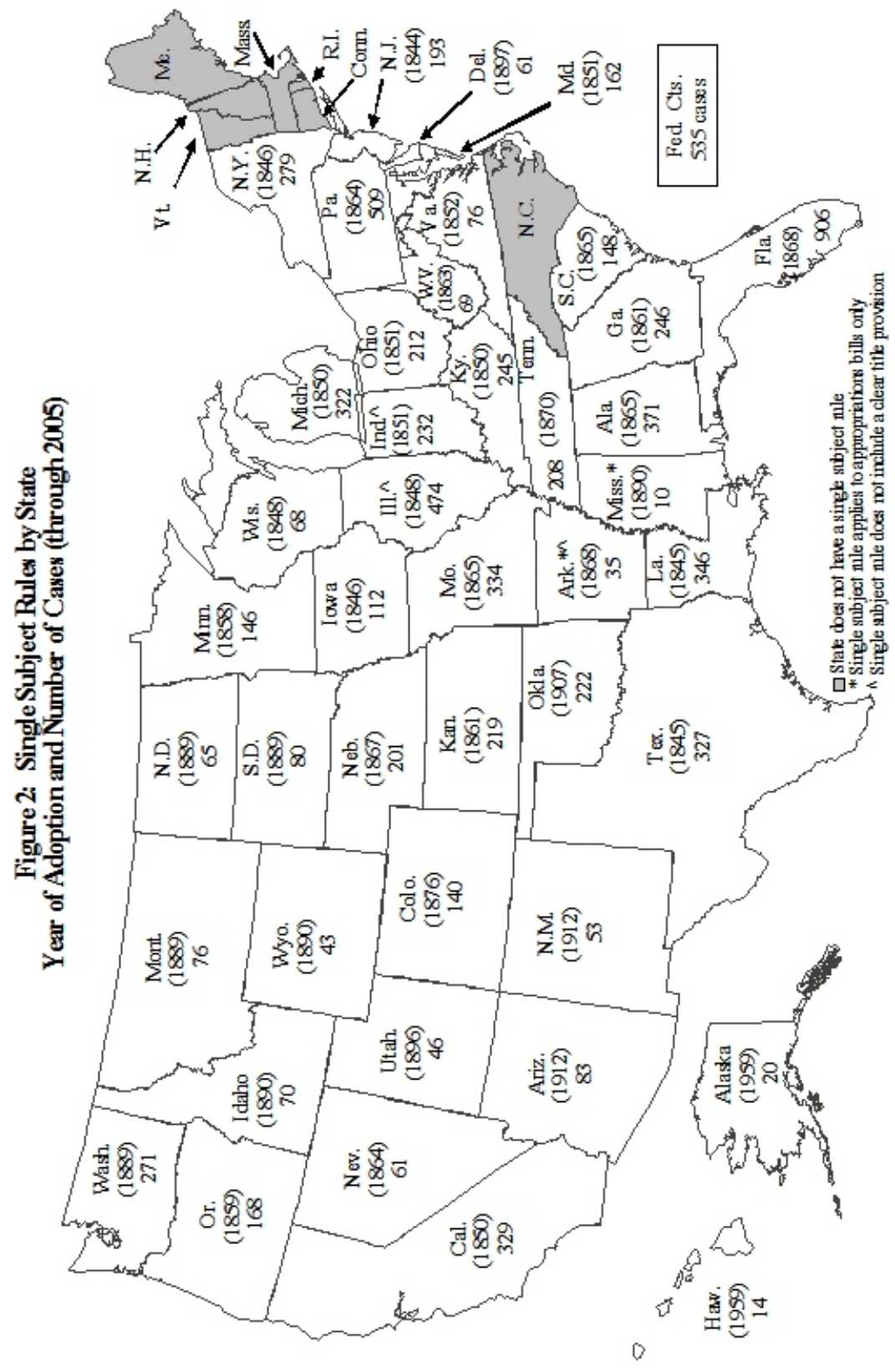




\section{Problems in the Application of the Single Subject Rule}

While Part I provided a macro overview of the single subject rule, including its history, purposes, and rates of litigation, this Part takes a micro approach, digging into the cases and exploring courts' approaches to single subject disputes.

I will first discuss judicial deference and the appropriations exception; in many states, appropriations bills are exempted from the single subject requirement. I will then review courts' efforts to identify a framework for approaching single subject disputes. Defining a single subject is a constant challenge, and courts have developed rough and ineffective tests for doing so. Next, I will cover severability, the notion that courts can, upon finding a violation of the single subject rule, sever just the offending provision and uphold the rest of the act. ${ }^{99}$ This Part concludes by summarizing the state of single subject jurisprudence and exposing the limitations of the rule. ${ }^{100}$

\section{A. Judicial Deference and the Appropriations Exception}

Judges tend to shy away from invalidating laws. In the words of an Arizona court, "[n]o task . . . is more grave than passing upon the constitutionality of legislation." 101 Thus, it comes as no surprise that courts adopt - or at least pretend to adopt - a cautious stance in single subject disputes, interpreting the rule liberally and resolving all doubts in favor of the legislature. ${ }^{102}$ In Iowa, legislative acts are only invalidated when they "clearly, plainly and palpably" violate the single subject rule. ${ }^{103}$ In South Dakota, "the conflict between the statute and the constitution must be plain and manifest" before a law will be struck down on single subject grounds. ${ }^{104}$ For over a century, Ohio's single subject rule was merely directory, not mandatory. ${ }^{105}$

99. See Ruud, supra note 4, at 399-400.

100. I will focus on generalizations rather than in-depth analysis of individual cases. For such analysis, see, e.g., Hoffer \& McDade, supra note 18.

101. Litchfield Elementary Sch. Dist. v. Babbitt, 608 P.2d 792, 800 (Ariz. Ct. App. 1980).

102. See, e.g., Dague v. Piper Aircraft Corp., 418 N.E.2d 207, 214 (Ind. 1981).

103. Iowa v. Soc. Hygiene, Inc., 156 N.W.2d 288, 290 (Iowa 1968).

104. Simpson v. Tobin, 367 N.W.2d 757, 767 (S.D. 1985).

105. Compare State ex rel. Dix v. Celeste, 464 N.E.2d 153, 156 (Ohio 1984)(stating that a "long line of unbroken cases" hold that Ohio's single subject rules are "directory rather than mandatory"), with Simmons-Harris v. Goff, 711 N.E.2d 203, 215 (Ohio 1999) ("Despite the 'directory' language of Dix, the recent decisions of this court make it clear that we no longer view the one-subject rule as toothless."). In the early years of single subject litigation, several state courts considered the rule to be merely directory. See State ex rel. Chase v. Rogers, 10 Nev. 250, 252 (1875). 
Consistent with a deferential approach, courts often grant legislatures greater leeway when enacting appropriations bills. This is due to the fear of treading on an important part of the legislative process and also the recognition that the very "purpose of appropriations bills is to allocate monies for . . . multitudinous and disparate needs." state constitution specifically excludes appropriations bills from the single subject requirement. ${ }^{107}$ Other state constitutions contain no such exception, but judges still afford appropriations bills more flexibility. ${ }^{108}$

Although courts prefer not to enforce the single subject rule, they cannot ignore constitutional mandates. As a Maryland court expressed, "[d]espite this 'general disposition' of deference ... the 'single-subject' provision is still a part of our Constitution." 109 When single subject disputes arise, judges must formulate tests for determining whether the legislation at issue violates the rule.

\section{B. Defining a Single Subject: The Fumble for a Test}

To resolve single subject disputes, courts need only define the term "subject" and then decide if the legislation at issue contains more than one. At first blush, this may seem like a simple exercise. The constitutional language is clear, and "subject" is a common term, not a legalism. But in the law, the commonality of a term is less important than its plasticity. What constitutes a "subject" is inherently elusive, leading courts away from dictionaries and towards the fabrication of tests for measuring compliance with the single subject rule. These tests are exceptionally broad and fail to provide judges or litigants with much guidance.

106. Flanders v. Morris, 558 P.2d 769, 773 (Wash. 1977).

107. ILl. CONST. art. IV,$\S 8(\mathrm{~d})$ ("Bills, except bills for appropriations and for the codification, revision or rearrangement of laws, shall be confined to one subject. Appropriation bills shall be limited to the subject of appropriations.").

108. Compare, e.g., WASH. Const. art. III (containing no exception to the single subject rule for appropriations bills), with Flanders, 558 P.2d at 773 ("Clearly, greater latitude must be granted the [Washington] legislature in enacting multi-subject legislation under the appropriations bill...."). Some courts will invalidate appropriations acts if logrolling or riding is obvious. For example, if a provision in an appropriations bill is unrelated to state spending, the legislation may be declared invalid. See Dep't of Educ. v. Lewis, 416 So. 2d 455, 460 (Fla. 1982).

109. Porten Sullivan Corp. v. State, 568 A.2d 1111, 1118 (Md. 1990). 


\section{1. "Subject" Cannot Be Objectively Defined}

In his classic treatment of single subject rules, Ruud recognized the difficulty of defining a subject, noting that "[s]ubjects are organized and classified as such in the law for a variety of reasons - for reasons of history, legal theory, convenience, functional relationships and the like." ${ }^{110}$ Several years later, Professor Daniel Lowenstein put it more bluntly: "a subject is in the eye of the beholder." 111 Topics or themes cannot objectively be classified into one subject or another. ${ }^{112}$ This is because subjects are defined not by logic but by social context. ${ }^{113}$ To illustrate using some of Lowenstein's examples, the terms "torts," "biology," "medicine," and "surgery" probably fall under the subject of "university education." "114 Most people, however, would not place all of them under the subjects "legal education," "medical education," or "science." 115 Thus, the context in which ideas are combined is essential in understanding whether they relate to the same subject. ${ }^{116}$ To confound the issue, context can be interpreted differently. One doctor might argue that all four of Lowenstein's terms fall under the subject "medical profession." Another might counter that only the last three terms are pertinent, and a third, cynical doctor might insist that only the first term matters!

The point is that subjects are, as the word itself implies, subjective. No matter how disparate they seem, judges cannot study the provisions of an act and declare with any confidence that they embrace more than one subject. To do so would require a transcript of the thoughts of every legislator who voted for the bill.

Some courts have refused to acknowledge this stumbling block. Consider, for example, the following passage quoted by the Supreme Court of Kansas in 1980:

110. Ruud, supra note 4, at 411 . Ruud was not the first commentator to identify this difficulty. See Manson, supra note 79, at 159-60 ("This identification of the object of the statute is the most difficult problem raised by the title-body clause. ... There are objects upon objects. . . There always will be differences of opinion as to what is the object of a statute.").

111. Lowenstein, supra note 20, at 938.

112. See id. at 938-39.

113. See id.

114. See id. at $940-42$.

115. See id.

116. See id. at 940-42. This point was made more explicitly in Lowenstein, supra note 18, at 47 . 
[T] he title to an act may include more than one subject, provided all can be so united and combined as to form only one single, entire, but more extended subject; yet, neither the title to the act nor the act itself can contain more than one subject, unless all the subjects which it contains can be so united and combined as to form only one single subject. ${ }^{17}$

This represents a formal, doctrinal, and hopeless attempt to reason around the problem.

Fortunately, many courts avoid such tautologies. The Supreme Court of Indiana summarized the issue nicely: "For purposes of legislation, 'subjects' are not absolute existences to be discovered by some sort of a priori reasoning, but are the result of classification for convenience . . . and for greater effectiveness in obtaining the general purpose of the ... act." 118 The understanding reflected in this quote has led courts away from attempts to define "subject" and towards the development of more flexible tests.

\section{Courts Have Formulated a Variety of Tests for Determining Compliance} with the Single Subject Rule

Courts have fabricated a number of tests that seek to guard against the abuses the single subject rule was meant to prevent without obstructing important legislation. ${ }^{119}$ The language of the tests is terse and varies across jurisdictions. Indiana courts ask whether there is a "reasonable basis" for grouping together the disparate parts of a bill. ${ }^{120}$ In Illinois, provisions must have a "natural and logical connection" to be considered one subject. ${ }^{121}$ Oregon courts look for a "unifying principle logically connecting all provisions in the act." 122 The Minnesota legislature must demonstrate that proposals are either related "logically or in popular understanding" or are "germane" to one subject. ${ }^{123}$ This germaneness standard is popular; Pennsylvania, Maryland, and Kansas also follow it, just to name a few. ${ }^{124}$

117. State ex rel. Stephan v. Thiessen, 612 P.2d 172, 178-79 (Kan. 1980) (quoting State v. Barrett, 27 Kan. 213 (1882)).

118. Dague v. Piper Aircraft Corp., 418 N.E.2d 207, 214 (Ind. 1981) (quoting Indiana ex rel. Test v. Steinwedel, 180 N.E. 865,868 (Ind. 1932)).

119. See, e.g., Stephan, 612 P.2d at 178 .

120. Dague, 418 N.E.2d at 214.

121. Johnson v. Edgar, 680 N.E.2d 1372, 1379 (Ill. 1997).

122. McIntire v. Forbes, 909 P.2d 846, 856 (Or. 1996).

123. Assoc. Builders \& Contractors v. Carlson, 590 N.W.2d 130, 136 (Minn. Ct. App. 1999).

124. See Stephan, 612 P.2d at 179; Porten Sullivan Corp. v. State, 568 A.2d 1111, 1120 (Md. 1990); DeWeese v. Weaver, 824 A.2d 364, 370 (Pa. Commw. Ct. 2003). 
While the language of the tests differs, their purpose is the same: to identify bills that, based on a commonsense interpretation of context, contain provisions that are unrelated to one another. The theory is that such bills are the product of logrolling or riding and should be struck down. ${ }^{125}$ Many courts use these same tests to determine whether a disputed act is too confusing, ${ }^{126}$ another occurrence that the single subject rule-and the title provision in particular - seeks to prevent. The rationale is that disparate measures cannot be simultaneously enacted in a manner that is comprehensible to citizens and their representatives. ${ }^{127}$ Other courts use a separate analysis to decide whether an act is too confusing or opaque. ${ }^{128}$ This approach parses the single subject rule into its "subject" and "title" requirements. ${ }^{129}$

Regardless of how courts structure their analyses, they face the same challenge of assessing whether the context in which an act was passed justifies the combination of the proposals at issue. Unfortunately, they often fail to disclose the ultimate basis for their decisions.

Many courts that uphold diverse legislation as long as the subjects contained in a particular bill are "reasonably germane" ... or as long as the court can discern a "rational unity" among them, do so without unpacking or defining those phrases. Indeed, the opinions often convey a sense of the judicial unwillingness to develop a meaningful standard for challenges to legislation. ... Though it is overstated, there is some truth to ... [the] observation that no criteria for subject-title requirements has [sic] been developed by judicial action. ${ }^{130}$

The tests courts have developed for coping with single subject disputes may represent an improvement over any effort to define "subject." But they are far from precise, leaving judges with little guidance and much discretion. On the one hand, that discretion offers valuable flexibility in dealing with the sensitive issue of statutory review. But, on the other hand, discretion opens

125. See supra text accompanying notes 64 and 72 .

126. See, e.g., Bernstein v. Comm'r of Pub. Safety, 351 N.W.2d 24, 25 (Minn. Ct. App. 1984) (stating that the purpose of the single subject rule is to prevent voter confusion and applying a germaneness test).

127. Cf. DeWeese, $824 \mathrm{~A} .2 \mathrm{~d}$ at 369 ("[A] bill addressing a single topic is deemed more likely to obtain a considered review than one addressing many.").

128. See, e.g., MotorClub of Iowa v. Dep't of Transp., 265 N.W.2d 151, 152-53 (Iowa 1978) (stating that the issue is not whether the act contains unrelated provisions but whether its title is sufficient to prevent surprise in legislation, which is a separate component of the single subject rule).

129. Many courts collapse the subject and title components of the single subject rule into one analysis. See Denning \& Smith, supra note 12, at 994 . Other courts, however, insist that the two components should be examined separately. See, e.g., Harbor v. Deukmejian, 742 P.2d 1290, 1300 (Cal. 1987).

130. Denning \& Smith, supra note 12, at 996 (quoting Dodd, supra note 87). 
the door for inconsistency and "personal prejudices and political and subjective considerations by the court. ..."131 In my view, the discretion is harmful. Courts are not using vague tests in order to judiciously and selectively enforce the single subject rule. They use such tests because no one has developed a more sensible and concrete approach to the problem.

\section{Remedying Single Subject Violations}

Upon finding a single subject violation, many courts declare the offending legislation void in its entirety. ${ }^{132}$ Other courts, however, seek to sever and strike down only those provisions that offend the single subject rule, upholding the rest. ${ }^{133}$ In some states, limited judicial severing is required by the constitution. The Arizona Constitution, for example, explicitly commands judges to sever any provision from an act that is not properly expressed in the act's title. ${ }^{134}$ In other states, courts have inferred the power to sever acts that violate the rule. ${ }^{135}$

The general rationale for severing is that it represents a "far less disruptive" course of action than does complete nullification. ${ }^{136}$ This may be especially true when legislative riders are present. Rather than striking down the entire bill - all of which, with the exception of the rider, was supported by a legislative majority - severing allows the court to extract the rider and let the popular provisions stand. ${ }^{137}$ Furthermore, there is a "strong presumption" that

131. See Manson, supra note 79, at 159 .

132. See, e.g., Litchfield Elementary Sch. Dist. v. Babbitt, 608 P.2d 792, 804 (Ariz. Ct. App. 1980) (declaring that severing "injects the courts more deeply than they should be into the legislative process"); see also Ruud, supra note 4, at 399 (stating that when multiple subjects are included in a single act, courts generally invalidate that act in its entirety).

133. See, e.g., Simpson v. Tobin, 367 N.W.2d 757, 768 (S.D. 1985) ("Unconstitutional provisions of a statute may be extracted and the remainder left intact.").

134. See ARIZ. Const. art. IV, pt. 2, § 13 (" $[I]$ f any subject shall be embraced in an Act which shall not be expressed in the title, such Act shall be void only as to so much thereof as shall not be embraced in the title."). This peculiar wording implies that bills can contain multiple subjects so long as they are all expressed in the title. Yet such a construction runs contrary to the preceding clause in the Arizona constitution, "Every Act shall embrace but one subject and matters properly connected therewith." Id.

135. For example, Minnesota courts inferred the power of severability when the state supreme court concluded that, in light of the state constitutional language, it is equally reasonable to sever disputed legislation as it is to invalidate it. See Assoc. Builders \& Contractors v. Ventura, 610 N.W.2d 293, 305 (Minn. 2000)

136. $I d$.

137. See Ruud, supra note 4 , at 400. 
legislatures prefer severance to invalidation. ${ }^{138}$ Thus, by severing provisions, courts are merely carrying out legislative intent. ${ }^{139}$

Of course, the danger of severing is that courts may make mistakes. Identifying riders is challenging. ${ }^{140}$ And when the issue is not riding but logrolling and the bill contains multiple subjects, courts must determine which subject is "dominant" or of "greater dignity." 141 This can lead to arbitrary decision-making. Nevertheless, a number of courts in recent years have severed acts that were deemed to violate the single subject rule. ${ }^{142}$

\section{Summary: The State of Single Subject Jurisprudence}

The single subject rule remains, even after a century-and-a-half of life, a source of uncertainty. Not all courts recognize all of the purposes of the rule, and among the purposes they do recognize, there is sometimes hesitancy to flesh them out. Resolution of single subject disputes turns on vague tests that rely as much on judicial commonsense as legal analysis. As one judge stated, it is unclear "whether characterizing the 'one subject' of a measure is a usable legal test ... or whether it simply compels endless conceptual manipulation, controversy, and litigation." 143 This leads some courts to apply the rule aggressively while others take a softer approach. ${ }^{144}$ Finally, courts diverge in their treatment of single subject violations. Some courts mechanically strike down acts, while others sever some provisions and let others stand. Taken together, these facts make clear that single subject jurisprudence is unsteady. Reading the opinions of a given court does not provide firm guidance on how that court will resolve future single subject disputes.

These problems should not be attributed to judges but rather the wording of the rule itself. "Subjects" are hard to define, and thus the rule's text provides little guidance. In addition, the text is disconnected from the purposes of the rule. The rule does not forbid logrolling or riding; it forbids bills from containing multiple subjects. ${ }^{145}$ But there is no reason to suppose

138. Porten Sullivan Corp. v. State, 568 A.2d 1111, 1122 (Md. 1990).

139. See id. n.8.

140. Ruud, supra note 4 , at 400.

141. Cf. id. at 399 ("Several cases, however, have suggested that the court should determine whether one of the subjects is of greater dignity or is the dominant subject . . ..").

142. See, e.g., State ex rel. Ohio Civil Serv. Employees Ass'n v. State Employment Relations Bd., 789 N.E.2d 636, 642 (Ohio Ct. App. 2003).

143. Or. Educ. Ass'n v. Phillips, 727 P.2d 602, 612 (Or. 1986) (Linde, J., concurring).

144. Cf. supra note 92 (identifying divergent success rates in single subject disputes in three states).

145. See Ruud, supra note 4, at 448. 
that logrolling and riding occur only in bills addressing multiple subjects. One could imagine legislators trading votes over several unpopular tax breaks that are cobbled together in one bill and passed with majority support. Such logrolling would fly under the judicial radar if the provisions had an easily recognizable theme, say, "corporate taxation." Similarly, an unpopular rider that channels funds to a corrupt builder could be appended to a bill addressing "state highway construction." Again, this would fall outside of the single subject rule's purview. In these senses, the rule is underinclusive.

The rule is underinclusive in another sense: it only captures logrolling that takes place in a single bill. ${ }^{146}$ Among stable coalitions of legislators, logrolls can be spread across multiple bills. Legislators could trade votes to secure passage of two measures, $\mathrm{A}$ and $\mathrm{B}$, that are independently unpopular. The legislators could then subject A and B to separate votes. Assuming the legislators adhered to their promises, bills A and B would both pass, and neither one would offend the single subject rule.

The rule is also overinclusive. Not every act that addresses multiple subjects is the product of logrolling or riding. Legislators have incentives to package together unrelated but independently popular provisions in a single bill. Doing so lowers transaction costs by preventing legislators from wasting time on multiple sets of deliberations and voting sessions when only one would suffice. ${ }^{147}$ This practice is valuable when time is short and legislators have multiple issues to address. Even if this is done with full disclosure and complete transparency, such composite acts are liable to be struck down on single subject grounds.

In short, the single subject rule itself, not just the jurisprudence that surrounds it, is flawed. Even if "subjects" could objectively be defined, logrolls and riders would continue to slip through the legislative process, and genuinely popular legislation would get struck down. It comes as no surprise that, in practice, judges occasionally make mistakes. Some missteps are unavoidable. But it does come as a surprise that even in a world of perfect single subject adjudication, the rule would still lead to errors.

146. See id.

147. Cf. Conner v. Mayor of New York, 5 N.Y. 285, 297 (1851) (Foot, J., concurring) (“ $[\mathrm{H}] \mathrm{ow}$ absurd and useless it would have been ... for the legislature to have repeated four times, in four different laws, the same title and provisions, with the only exception of the name of the office, and how equally absurd and useless to pass a separate act ... to regulate each of the incidents and consequences of the change [just to satisfy the single subject rule]."). 
Improving single subject jurisprudence requires courts to look first to the rule's purposes, not the literal text of the rule. Part III is devoted to understanding those purposes.

\section{Reevaluating the Single Subject Rule in Light of Public Choice Theory}

While the last Part illustrated the inconsistency that characterizes single subject adjudication, this Part examines the fundamental purposes underlying the rule. Courts often rely on historical expositions when discussing the purposes of the rule, and many of these date from the 19th century. ${ }^{148}$ Understanding of legislative processes has improved significantly since then, and that knowledge should be incorporated into single subject adjudication. In this regard, the insights of public choice theory-broadly defined as the application of economic principles to political institutions ${ }^{149}$ - are instructive.

This Part revisits the purposes of the single subject rule in light of public choice. I will show that logrolling can be considerably less malevolent then perceived, but that riding presents a genuine and distinct threat to majority rule. Improving political transparency is an important goal of single subject rules, but rigid application of the rule can be counterproductive in this regard. Finally, a strict single subject rule does strengthen governors' veto power, but it also curtails governors' ability to orchestrate legislative logrolls. Consequently, the overall impact of a strict single subject rule on executive authority is uncertain.

\section{A. The Vexatious Worm Revisited: Logrolling and Cooperative Surplus}

Logrolling is tantamount to vote trading. ${ }^{150}$ To ensure that an unpopular bill receives enough votes for passage, supporters of the bill must bargain with non-supporters. ${ }^{151}$ Explicit vote trading occurs if the supporters convince others to vote for the bill in exchange for their votes on a different measure.

148. See, e.g., Geja's Cafe v. Metro. Pier \& Exposition Auth., 606 N.E.2d 1212, 1220 (Ill. 1992) (using a quotation from an 1865 opinion, People ex rel. Drake v. Mahaney, 13 Mich. 481, 494-95 (1865), to describe the purposes of the single subject rule).

149. See, e.g., Robert D. Cooter, The Stra teg ic Constitution 7 (2000); Daniel A. Farber \& Philip P. Frickey, Law and Public Choice: A Critical Introduction 7 (1991).

150. See Hasen, supra note 58 and accompanying text; James M. Buchanan \& Gordon Tullock, The Calculus of Consent 132 (1965). support).

151. Cf. supra note 29 (noting that logrolling can take place among provisions that have majority 
Of course, that different measure may never reach the floor of the legislature, or the supporters may renege on their promise. ${ }^{152}$ Thus, non-supporters often prefer to give and receive simultaneously by adding a measure they favor to the supporter's bill. The resulting two-part bill is a logroll, and the vote trading is implicit. Neither side actually swaps votes but rather agrees tacitly to endorse the bill. In this way, each party benefits from the other's backing, receiving its preferred provision and tolerating the other side's measure. Logrolling in this scenario looks suspiciously like a common and considerably less-maligned practice: legislative compromise. ${ }^{153}$

For years, public choice scholars have argued that vote trading can benefit legislators as well as their constituents. ${ }^{154}$ The theory begins with the recognition that, in majority rule voting, a person who is passionately opposed to a measure and a person who is modestly favorable but essentially indifferent are given equal weight. ${ }^{155}$ If a bare majority favors a bill, however slightly, the bill will become law, even if to an outraged minority it represents legislative anathema. In this situation, it seems "obvious that both [groups] could be made better off . . . if [those] strongly opposed should be permitted in some way to 'trade' ... with the relatively indifferent supporter[s] of the proposed measure." ${ }^{156}$ By giving up votes on provisions in which they are uninterested and receiving votes on provisions that they value, legislators can improve their positions. ${ }^{157}$ This improvement represents what economists call a "cooperative surplus."

152. While valid, these arguments can be overstated. Because legislators interact with one another repeatedly, they may cooperate across separate bills to maintain or improve their reputations.

153. See Hasen, supra note 58, at 1340 ("Call the practice [of logrolling] 'vote buying' and it sounds like it should be illegal. But call it, as an Alaska statute does, 'legitimate compromise between public servants' and it sounds laudatory.") (internal citations omitted).

There are three kinds of compromises legislators can strike: substantive compromises, where a legislator proposes a bill and then agrees to change the substance of it to secure enough votes for passage; length compromises, where a legislator proposes a bill and then, without changing the original bill, adds on other measures to secure enough votes for passage; and hybrid compromises, which combine the other two. Cf. Maxwell L. Stearns, The Public Choice Case Against the Item Veto, 49 Wash. \& LeE L. Rev. 385, 413-14 (1992). For ease of explanation, this paper focuses on length compromises, but the analysis for all three is the same.

154. See, e.g., CoOTER, supra note 149, at 51-57; Eskridge, Frickey \& GARrett, supra note 18, at 172; BuCHANAN \& TUlLOCK, supra note 150, at 132-34.

155. See Buchanan \& Tullock, supra note 150, at 132.

156. $I d$.

157. See CoOTER, supra note 149, at 53 (arguing that where transactions costs are low, legislators will bargain such that the combination of laws is efficient relative to their preferences). This notion is derived more generally from the Coase Theorem. See id. 
The following example will concretize this argument. Assume that a legislature has just three members, and they are making decisions about three separate policies, A, B, and C. ${ }^{158}$ Legislator 1 passionately supports A and mildly opposes B and C. Similarly, Legislator 2 ardently favors B and modestly dislikes A and C. Legislator 3 strongly supports $\mathrm{C}$ and bears a slight aversion towards A and B. These preferences are summarized in Table 1. The status quo represents no change in policy and is indicated by "SQ." Utility reflects the personal pleasure (or, when negative, displeasure) that each legislator experiences when the corresponding policy is enacted.

Table 1

\begin{tabular}{|c|c|c|c|c|c|}
\hline \multicolumn{2}{|c|}{ Legislator 1 } & \multicolumn{2}{c|}{ Legislator 2 } & \multicolumn{2}{c|}{ Legislator 3 } \\
\hline Policy & Utility & Policy & Utility & Policy & Utility \\
\hline A & 20 & B & 20 & C & 20 \\
\hline A + B + C & 15 & A + B + C & 15 & A + B + C & 15 \\
\hline SQ & 0 & SQ & 0 & SQ & 0 \\
\hline B & -2 & C & -2 & A & -2 \\
\hline C & -3 & A & -3 & B & -3 \\
\hline
\end{tabular}

If the policies are voted upon separately, none will receive majority support. This is because two of the three legislators prefer the status quo to any given policy. To illustrate, policy B will receive support from Legislator 2; enacting B would increase her utility by 20 units over the status quo. However, Legislators 1 and 3 would vote against policy B, as it makes both of them worse off than the status quo. Similarly, A and C each will receive one favorable vote and two unfavorable votes. In the absence of bargaining, the legislature will be left with the status quo, which yields zero utility for everyone.

If bargaining is allowed, the legislators may agree to logroll $\mathrm{A}, \mathrm{B}$, and $\mathrm{C}$ into one bill that will receive unanimous support. This will reward each member with her most favored policy, albeit at the cost of implementing the others' programs. Each legislator will experience a net gain of 15 utility-20 from her preferred policy less 5 from the other policies-for a total "social" gain of 45 . This figure, 45 utility, is the cooperative surplus of the bargain,

158. In the interest of simplicity, this example assumes that $\mathrm{A}, \mathrm{B}$, and $\mathrm{C}$ are independent from one another and unrelated - they do not rely on one another to be effective, nor do they contradict each other. 
the amount by which the legislators are collectively better off due to logrolling.

This example shows plainly the potential gains from legislative bargaining. It is, however, simplistic. For one, it implies that every legislator plays a role in and benefits from every bargain. In reality, this is not the case. Not all bills receive unanimous support, and some legislators are excluded from legislative bargains and may be left worse off because of them. ${ }^{159}$ To illustrate in the context of the example, Legislators 1 and 2 could logroll just $\mathrm{A}$ and $\mathrm{B}$. That combination would produce greater utility for them (18 and 17, respectively) than would the combination of $A, B$, and $C$ (15 apiece). In that scenario, Legislator 3 would be left out of the deal and would suffer a utility loss of $5 .{ }^{160}$

In this iteration of the bargain, aggregate social utility is still positive (Legislators 1 and 2 collectively gained 35 utility, and Legislator 3 lost 5). Legislator 3 suffered from this particular bargain, but there is no reason to suppose that this will systematically be the case. Next time she may benefit at the expense of Legislator 1 or 2 . On the whole, logrolling is still socially beneficial. Unfortunately, a reworking of the utility figures can change this rosy picture.

159. Indeed, leaving some legislators out of the bargain may improve the positions of the legislators who participate in it. See, e.g., CoOter, supra note 149, at 73 (reasoning that because a successful coalition of legislators must distribute the gains from a bargain among its members, there is an incentive to form the smallest possible coalition in order to maximize per capita gains). But see Barry R. Weingast, A Rational Choice Perspective on Congressional Norms, 23 AM. J. PoL. SCI. 245 (1979) (developing a rational choice explanation for the absence of minimum winning coalitions in "distributive" policymaking); Kenneth A. Shepsle \& Barry R. Weingast, Political Preferences for the Pork Barrel: A Generalization, 25 AM. J. PoL. SCI. 96 (1981) (same).

160. Rather than simply accepting his fate, Legislator 3 could propose a logroll of B and C. This combination would yield more utility for Legislator 2 (18 rather than 17) and Legislator 3 (17 rather than $-5)$ than would the combination of A and B. Legislator 1 could then propose the combination of A and C. Legislator 2 could respond by re-proposing A and B, completing the circle. This sort of legislative cycling could continue indefinitely. See CoOTER, supra note 149, at 40-43, 58-59 (drawing this conclusion from Arrow's chaos theorem); see also Mueller, supra note 28, at 108 (proving that the conditions that give rise to logrolling also give rise to cycling). In theory, legislative cycling is common, but in practice it may be rare. See id. at 112-14; FARBER \& FrICKEY, supra note 149, at 47-48. 
Table 2

\begin{tabular}{|c|c|c|c|c|c|}
\hline \multicolumn{2}{|c|}{ Legislator 1 } & \multicolumn{2}{c|}{ Legislator 2 } & \multicolumn{2}{c|}{ Legislator 3 } \\
\hline Policy & Utility & Policy & Utility & Policy & Utility \\
\hline A & 20 & B & 20 & C & 2 \\
\hline A + B + C & 15 & A + B + C & 15 & A + B + C & -48 \\
\hline SQ & 0 & SQ & 0 & SQ & 0 \\
\hline B & -2 & C & -2 & A & -20 \\
\hline C & -3 & A & -3 & B & -30 \\
\hline
\end{tabular}

Now Legislator 3 mildly supports $\mathrm{C}$ and is strongly opposed to A and B. If Legislators 1 and 2 logroll A and B, they still gain 35 utility, but Legislator 3 loses 50, and thus aggregate utility is negative. In this circumstance, logrolling is socially harmful. ${ }^{161}$

To preempt this outcome, Legislator 3 could bargain with the other legislators and convince them not to pass A and B. For example, she could "pay" Legislator 2 with future votes and other favors to break the logroll. Legislator 3 would be willing to pay any amount up to the equivalent of 50 utility (her loss if A and B become law) to achieve this result. Legislator 2 would be willing to break the logroll for any amount greater than 17 (her gain from logrolling A and B). Whether this maneuver is successful hinges on the transaction costs of political bargaining. If the costs are low, Legislators 2 and 3 can strike a deal, and bills A and B will not pass. Utility will be redistributed from 3 to 2 , but aggregate utility will not decline. If the transaction costs of bargaining are high, Legislators 2 and 3 may not be able to reach a deal. Time may be too short, or Legislator 3 may lack the capital (e.g., votes) to offer Legislator $2 .^{162}$ In this case, the original logroll of A and $\mathrm{B}$ will proceed, and aggregate utility will decline. This example yields a prediction: as the transaction costs of political bargaining rise, logrolling will more often be harmful. ${ }^{163}$

Note that, irrespective of the aggregate utility effects, every instance of logrolling makes a majority of legislators better off. In the first example,

161. Riker and Brams generalize this result and show that, in certain circumstances, every legislator has an incentive to engage in one or more trades in a sequence, and yet every legislator is left worse off when all the trades in the sequence are carried out. See William H. Riker \& Steven J. Brams, The Paradox of Vote Trading, 67 Am. PoL. Sci. Rev. 1235, 1241 (1973).

162. Additionally, high transaction costs may make it impossible for any proposed deal to be finalized, in which case the offer from Legislator 3 to Legislator 2 could initiate a round of legislative cycling with no apparent end. Cf. Mueller, supra note 28, at 108-12.

163. Cf. COOTER, supra note 149 , at 53-54. 
logrolling A, B, and C improved the positions of all three legislators. Each moved up her list of preferences from the status quo to $\mathrm{A}+\mathrm{B}+\mathrm{C}$. Likewise, in the last example, the bargain between Legislators 1 and 2 increased their satisfaction. Both moved upwards from the status quo. ${ }^{164}$ Thus, from a purely majoritarian perspective, logrolling looks benign. Every instance of logrolling makes all of the participants - and thus a majority of legislators - better off.

A final, significant wrinkle bears mentioning. The above examples refer only to the implications of logrolling for legislators; constituents are ignored. If legislators accurately represent all of their constituents, then the analysis carries over: legislators and citizens will generally experience the same effects from vote trading. But this is unrealistic. Preferences vary, and among the constituents of a given legislator, some will benefit from a particular vote trade while others will suffer harm. At the extreme, legislators may trade votes in order to curry favor with powerful interest groups but leave most of their constituents - and society as a whole - worse off.

The bottom line on logrolling is that it has the capacity to improve social welfare but also to diminish it. ${ }^{165}$ The majority of legislators who participate in a legislative bargain will always benefit; they move up their list of preferences. But the external effects on the minority, non-participant legislators may be so large that the aggregate social return is negative. Similarly, some constituents will gain from a particular vote trade but others will suffer harm. Whether more constituents gain than lose-or whether the aggregate utility gains to constituents exceed the losses - is indeterminate. In short, the precise effects of logrolling can only be measured empirically.

\section{B. Riders: Manipulations of the Legislative Process}

Riding occurs when an unpopular bill get attached to a popular one and then "rides" the popular bill through the legislature. ${ }^{166}$ Commentators

164. For Legislators 1 and $2, \mathrm{~A}+\mathrm{B}$ would be above $\mathrm{A}+\mathrm{B}+\mathrm{C}$ in Tables 1 and 2 and below each legislator's most preferred option, A and B, respectively.

165. See Hasen, supra note 58, at 1343 ("In sum, the efficiency analysis of legislative logrolling is indeterminate."); see also Thomas Stratmann, Logrolling, in Perspectives on Public ChOICE: A HAndBook 322 (Dennis C. Mueller ed., 1997) (“Today, no consensus exists . . as to whether logrolling is on net welfare enhancing or welfare reducing ....").

166. See Rudd, supra note 4, at 391 . The term "rider" is often used more generally to refer to additions to a bill that are not germane to its original content and to substantive measures that get attached to appropriations bills. See Richard A. Riggs, Separation of Powers: Congressional Riders and the Veto Power, 6 U. Mich. J.L. Reform 735, 737-38 (1972-1973). 
generally characterize riding as a species of logrolling ${ }^{167}$ which may lead one to believe that the same analysis from the last section applies. This is not the case. Riding is a separate practice, and it can be distinguished from logrolling using the concept of exchange.

By definition, logrolling consists of exchange. When measures A and B are logrolled, the supporters of A vote for the combined bill because they benefit from the bargain; in exchange for their support of $B$, they receive votes in favor of A. Likewise, the supporters of B exchange their votes on A in order to secure majority support for B. Implicitly or explicitly, all of the participants in a logroll are striking a bargain. They give and they receive.

Riding does not involve exchange but rather manipulation of legislative procedures. In certain situations, an unpopular measure can get attached to a popular one, and the combined bill can be submitted to the full legislature for a vote. Depending on the rules of procedure, the information available to legislators and the transaction costs of haggling, the unpopular measure may be irremovable. In that circumstance, the combined bill amounts to a take-itor-leave-it offer. Legislators can only choose between the combined bill and the status quo. If the combined bill is superior, they will pass it, even if a majority would prefer not to enact the unpopular provision. In this scenario, no exchange has taken place. The supporters of the popular measure implicitly cast a vote for the unpopular one, but they neither like the unpopular one nor gain anything in exchange for their support of it. This observation leads to a definition of riders: a rider is a political measure that lacks majority support on its merits but whose opponents vote for it in sufficient numbers to ensure its passage despite not receiving compensation from the measure's supporters.

To clarify, consider the following situation. A legislature consists of ten members, three of whom compose a committee with exclusive jurisdiction over two separate policies, A and B. The seven non-committee members share the same preferences: they like A and oppose B. The three committee members also share the same preferences: they support both A and B. Table 3 expresses these preferences. As before, utility figures have been assigned to each measure, and "SQ" refers to the status quo. ${ }^{168}$

167. See supra note 32.

168. In the interest of simplicity, this example assumes that A and B are independent from one another and unrelated - they do not rely on one another to be effective, nor do they contradict each other. 
Table 3

\begin{tabular}{|c|c|c|c|}
\hline $\begin{array}{c}\text { Non-committee members } \\
\text { (Legislators 1-7) }\end{array}$ & \multicolumn{2}{c|}{$\begin{array}{c}\text { Committee members } \\
\text { (Legislators 8-10) }\end{array}$} \\
\hline Policy & Utility & Policy & Utility \\
\hline A & 5 & A + B & 8 \\
\hline A + B & 1 & B & 5 \\
\hline SQ & 0 & A & 3 \\
\hline B & -4 & SQ & 0 \\
\hline
\end{tabular}

Measure A enjoys unanimous support; all ten legislators prefer it to the status quo. Thus, the committee members have an incentive to report $\mathrm{A}$ to the full legislature, where it will pass. Measure B only commands minority support. The three committee members support it, but the other seven legislators do not. Therefore, the committee members have no incentive to report B to the full legislature, as it will be voted down. One final possibility remains. The committee members could combine the measures and report them to the full legislature as a single bill, AB. All ten legislators prefer AB to the status quo, and this option yields the highest utility for the committee members, 8 apiece. As a result, the committee members may choose this third option and report out the combined bill. If the seven non-committee members cannot excise measure B, they will vote for the combined bill, as it leaves them better off (one utility) than the status quo (zero utility).

In this scenario, B is a rider. It only has minority support (Legislators 8 through 10), but its opponents (Legislators 1 through 7) voted for it in sufficient numbers to ensure its passage, and they did not receive anything in exchange. They did not receive votes from the committee members on these or other issues. For example, had the committee members pledged their support on a future issue to some non-committee members in exchange for the non-committee members' support of B, B would be part of a logroll, not a rider. An exchange like that did not take place. Likewise, the non-committee members did not implicitly trade their votes on B for an opportunity to vote on their preferred choice, A. Because the committee has exclusive jurisdiction over A, it could use that as a bargaining chip. The committee members could agree to report out $\mathrm{A}$ only if the non-committee members agreed to support $\mathrm{B}$. Again, that would constitute a logroll - the committee members would be giving up measure $\mathrm{A}$, and the non-committee members would be giving up B. But that exchange did not take place, and nor would it in the scenario described above. The committee members do not need an inducement to send A to the full legislature; they would benefit from its passage. So even in the 
absence of measure B, the committee members would report out A. In sum, no exchange, implicit or explicit, took place. ${ }^{169}$

As with logrolling, the utility effects of riding are indeterminate. In the example above, the passage of $\mathrm{AB}$ would generate 31 utility (one unit from each of Legislators 1 through 7 and eight units from each of Legislators 8 through 10). This is suboptimal - the passage of A alone would generate 44 utility - but still superior to the status quo (zero utility). Reworking the figures could easily change these results. For example, if each committee member gained ten utility from $B$ rather than five, the passage of $A B$ would be optimal, generating 46 utility (one each from Legislators 1 through 7 and thirteen each from Legislators 8 through 10). By contrast, if Legislators 6 and 7 each suffered a utility loss of twenty from the passage of B, aggregate utility would be negative. Legislators 1 through 5 and 8 through 10 would still vote for $\mathrm{AB}$, and their collective gain would be twenty-nine. But the loss to Legislators 6 and 7 would be forty, leaving aggregate utility in the red. ${ }^{170}$ Since representation is imperfect, the utility effects of riding on society at large are even harder to judge. An instance of riding that yields an aggregate gain for legislators could create a collective loss for their constituents.

The observation that riding, like logrolling, can be socially beneficial or socially harmful emphasizes an important point: the distinction between these practices turns on process, not outcome. An instance of logrolling and an instance of riding could yield identical aggregate welfare effects. But the processes underlying those outcomes would differ. The logroll would result from bargaining and compromise, while the rider would stem from

169. One could dispute this claim on the ground that riders, while not part of an exchange over specific legislative provisions, are part of a meta-exchange over parliamentary design. In exchange for providing leadership services to the chamber, veto players are endowed with the power to attach self-serving riders to bills. Seen through this lens, every rider can be conceptualized as a component of a deeper institutional bargain.

The problem with this argument is that it has no limit. Surely committee chairs cannot append a never-ending stream of riders to popular bills, significantly reduce the value of legislation to other legislators and the public in the process, and always justify this behavior under the banner of institutional design. There must be a point at which their excesses go beyond the terms of the institutional contract. It is in this zone, when leaders have gone too far in their use of riders (but, for a variety of possible reasons, not so far that they are stripped of their posts) that a judicially enforced ban on riders is sensible. See infra Part IV.B.

170. If the transaction costs of political bargaining are low, Legislators 6 and 7 can strike a deal with other non-committee members, transferring votes or other favors to them in exchange for votes against $\mathrm{AB}$. Alternatively, they can bargain with the committee members and offer them something in exchange for a commitment not to attach $\mathrm{B}$ to $\mathrm{A}$ in the first place. If the transaction costs of bargaining are high, these arrangements may be infeasible. 
manipulations of legislative procedure, reliance on other legislators' limited information, and the high transaction costs of amendment.

Regardless of the utility effects, riding is anti-majoritarian: every instance of it leaves a majority of legislators worse off. In the example above, seven of the ten legislators preferred $\mathrm{A}$ to $\mathrm{AB}$, and yet they were forced to accept the latter. Put more generally, every instance of riding moves a majority down their list of preferences by forcing them to accept a favored provision and an unfavorable rider rather than just the favored provision. This contrasts with logrolling, every instance of which makes a majority better off by moving them up their list of preferences. ${ }^{171}$

This analysis of riders may, at first glance, appear to rest on rather restrictive assumptions. For a rider to become law, its supporters must be able to use a procedural device to attach it to a popular bill, and the rider's opponents must then be unable to remove it. I now will explain why these assumptions are reasonable.

\section{The Committee System Allows for the Attachment of Riders}

To understand how a rider gets attached to a bill requires an understanding of the legislative committee system. ${ }^{172}$ Most American legislatures are divided into committees, each with jurisdiction over a particular subject matter. Committees deliberate over bills that fall within their jurisdiction. Sometimes these bills are initiated and drafted by a committee member, and other times they are proposed by a non-member and then referred to the committee. As suggested in the example above, many committees have near-exclusive "gatekeeping" authority. ${ }^{173}$ The full legislature cannot vote on a bill unless the committee to which the bill was

171. Lowenstein identified this distinction in his analysis of the single subject rule. See Lowenstein, supra note 20 , at 962 ; see also supra note 32 and accompanying text.

172. There is no universally followed legislative process in the United States. The information I offer here is general and draws in part on research that was focused on the U.S. Congress, not the state legislatures that are constrained by the single subjectrule. Nevertheless, the discussion captures the essence of most state legislative procedures. See generally William J. Keefe \& Mor ris S. Ogul, The American Legislative Process: Congress and the States 53-75, 190-290 (10th ed. 2001) (noting the many similarities between Congress and state legislatures with respect to processes that are relevant to this paper).

173. On gatekeeping in the states, see $i d$. at 265 (explaining that with some exceptions, "there are few instances in which [committees] lose control of measures referred to them"). On gatekeeping more generally and in Congress, see Kenneth A. Shepsle \& Mark S. BoncheK, Analyzing Politics: Rationality, Behavior, and Institutions 327 (1997); see also Kenneth A. Shepsle \& Barry R. Weingast, The Institutional Foundations of Committee Power, 81 Am. PoL. SCI. Rev. 85, 87 (1987) (noting that legislative mechanisms exist by which to "pry the gates open," but they are rarely used). 
assigned consents. In other words, unless the committee "opens the gates," no bill within its jurisdiction can be passed. This system vests committees with a great deal of power. ${ }^{174}$

Much of the logrolling discussed in the last section takes place within committees; members bargain with one another over specific provisions in a given bill. ${ }^{175}$ Of course, non-committee members can also weigh in, offering support on a separate bill - which may or may not get attached to the present bill ${ }^{176}$ - in exchange for favors. Non-committee members cannot, however, directly alter the provisions of a bill while it is in committee.

This brief background is sufficient to explain how a rider gets attached to a bill in the first place. Since committee members have exclusive control over the legislation that falls within their jurisdiction and they cannot be forced to bargain, they can simply tack riders on. This can happen openly, where enough committee members support the rider that they unabashedly include it in the bill. ${ }^{177}$ Or it can happen in secret, where a committee member quietly writes in the rider during the drafting session. ${ }^{178}$

174. On the power of committees in state legislatures, see Wayne L. Francis, Leadership, Party Caucuses, and Committees in U.S. State Legislatures, 10 LEgis. STUD. Q. 243, 246 (1985) ("[A]t the committee level there is ample autonomy and the agenda-setting power of the chairman is widely recognized."); Wayne L. Francis \& James W. Riddlesperger, U.S. State Legislative Committees: Structure, Procedural Efficiency, and Party Control, 7 Legis. Stud. Q. 453, 469 (1982) ("[C]ommittee systems in state legislatures have become the principal centers of decision making."); and also Gary F. Moncrief et al., The Old Statehouse, It Ain't What It Used to Be, 21 Legis. StUD. Q. 57 (1996) (reporting that about 43\% of long-term state legislators perceived an increase in committee power over the previous fifteen years, while only about $17 \%$ perceived a decrease). On the power of committees generally, see SHEPSLE \& BoncheK, supra note 173, at 324-43; Shepsle \& Weingast, supra note 173; Keith Krehbiel, Kenneth A. Shepsle \& Barry R. Weingast, Why Are Congressional Committees Powerful?, 81 Am. Pol. ScI. Rev. 929 (1987); and also Gary W. Cox \& Mathew D. McCubbins, Legislative Leviathan: Party Government In the House 160-87 (1993) (discussing, among other things, the advantages conferred on the majority political party by the committee system in the U.S. House of Representatives).

175. Cf. Cox \& McCubBins, supra note 174, at 79, 248-49.

176. See id. at 248-49 (discussing "intercommittee logrolls" and the creation of omnibus bills that touch upon the jurisdiction of more than one committee).

177. Committee members could logroll several riders into a single bill. For example, Committee Member 1 could agree to support the addition of Committee Member 2's favored provision to a given bill in exchange for 2's support of the addition of 1's favored provision. By my definition, this would constitute logrolling at the committee level. However, this would not constitute logrolling with the full legislature. Although Committee Members 1 and 2 made an exchange among themselves, they did not offer anything, explicitly or implicitly, to other legislators. They expect their favored provisions to become law because other legislators cannot remove them from the combined bill, not because they bargained with other legislators and made an exchange that leaves a majority of all legislators in a superior position.

178. In November 2004, a dramatic example of this unfolded in the U.S. Senate when an unknown lawmaker or staffer "slipped a provision into an omnibus spending bill that would have allowed two committee chairmen to view the tax returns of any American." See Frist: Tax-returns Measure 


\section{Legislative Rules and Imperfect Markets for Votes Prevent Riders from} Being Excised

The committee system facilitates the attachment of riders, but it does not guarantee that riders will remain intact when they reach the floor of the legislature. To understand why riders are not always removed once they leave committee requires an understanding of legislative rules.

When a committee brings a proposed bill to the full legislature, a set of rules governs how the legislature will deliberate on that bill. ${ }^{179}$ The rules regulate the "amount of time devoted to debate, how that time is divided between proponents and opponents, and, most importantly, what amendments are in order, if any." 180 The rules may be pre-determined, or they may be tailored to the bill in question. ${ }^{181}$ With respect to allowing amendments, the rules can be arranged along a spectrum of restrictiveness, with a "closed rule" on one end and an "open rule" on the other. Under a closed rule, amendments are forbidden. ${ }^{182}$ The bill can be voted upon as is, but it cannot be amended. Under an open rule, amendments are unrestricted. ${ }^{183}$

A closed rule offers a number of potential benefits. It allows for expedient passage of important bills, prevents legislative cycling on the floor, and encourages reliance on specialized committees. ${ }^{184}$ But it also allows for riding. Committee members can attach a rider and then send the complete bill to the full legislature, where the chamber cannot remove it. This amounts to a take-it-or-leave-it offer from the committee. If the legislature prefers the

Indefensible, CNN.Com, Nov. 21, 2004, http://www.cnn.com/2004/ALLPOLITICS/11/21/tax.provision/ (last visited Mar. 6, 2006). Senate Majority Leader Bill Frist said "he did not know who was responsible for inserting the language." Id.

There is a debate over the degree to which committees at both the Congressional and state level are representative of their parent chambers. See, e.g., Keith Krehbiel, Information and Legislative Organization 10-11, 105-50 (1991); L. Marvin Overby et al., Committee Outliers in State Legislatures, 29 Legis. STUD. Q. 81 (2004). This issue is largely irrelevant to my thesis. Regardless of whether their policy goals are broadly in line with those of their colleagues, politicians rarely have identical preferences, and they always have incentives to attach riders to provide personal gains to themselves and their districts.

179. See Shepsle \& BoncheK, supra note 173, at 335 . In Congress, the rules are devised primarily by rules committees. In state legislatures, the rules come from rules committees as well as calendar committees, factions, and legislative leadership. See Keefe \& Ogul, supra note 172, at 264-65.

180. SHEPSLE \& BONCHEK, supra note 173, at 335.

181. See id.

182. See id. at $120-25,336$.

183. See id. at $125-32,335$.

184. For a discussion of these theories and others, see KrehBiel, supra note 178, at 151-91. 
"offer" to the status quo, it will pass the bill with the rider, even if most legislators would prefer the bill without the rider.

In a voting market with perfect information, costless political bargaining, long time horizons, and repeat play, riders would not survive under a closed rule. All riders would be discovered, and bills containing riders would be sent back to committee to be reworked. For any riders they attach today, legislators would rationally expect to be penalized in a future political exchange, and they would therefore have an incentive not to attach riders in the first place. But these conditions do not hold in the real world. Information is not perfect. Legislators may not know about a rider, or they may not know who proposed it and, thus, who they should punish. ${ }^{185}$ Political bargaining is not costless. Sending a bill with a rider back to committee may be infeasible if the bill is urgent or if other important bills are in the queue and the opportunity costs are substantial. And interactions among legislators are finite. Legislators come and go every couple of years; the incumbency rates in state legislatures tend to be lower than in Congress. ${ }^{186}$ Indeed, the mere threat of an electoral loss could lead an otherwise cooperative legislator to attach a self-serving rider to curry favor with his constituents. Thus, repeat play and reputation effects are insufficient to deter bad behavior. ${ }^{187}$ For these reasons, closed rules can facilitate riding.

In contrast to closed rules, open rules do not allow committees to make explicit take-it-or-leave-it offers, and this diminishes the opportunities for riding. Amendments can be used to excise riders on the floor. Still, it is possible for riders to slip through. "Pure" open rules are rare, and the number of allowable amendments is usually limited. Complex regulations govern the order in which amendments can be made and by whom, and this can limit the opportunities to remove riders. ${ }^{188}$ Moreover, legislatures operating under an open rule are subject to the same market imperfections as those using a closed

185. See supra note 178 and accompanying text.

186. In 1994, over ninety percent of the members of both houses of Congress were reelected. By contrast, "eighteen state houses and twenty-three state senates had turnover rates in excess of twenty-five percent between 1992 and 1994." KeEFe \& OGUL, supra note 172, at 106. In several states, newcomers made up about half of at least one of the legislative chambers. See id. at 163; see also Gary F. Moncrief et al., Time, Term Limits, and Turnover: Trends in Membership Stability in U.S. State Legislatures, 29 LEGIS. STUD. Q. 357 (2004) (noting that adoption of term limits for state legislators in about one-third of the states has abated a downward trend in turnover rates).

187. For a brief discussion of repeat play in legislatures, see Barry R. Weingast \& William J. Marshall, The Industrial Organization of Congress; or, Why Legislatures, Like Firms, Are Not Organized as Markets, 96 J. Pol. Econ. 132, 141-42 (1988).

188. See Barry R. Weingast, Floor Behavior in the U.S. Congress: Committee Power Under the Open Rule, 83 Am. Pol. Sci. Rev. 795, 800-01 (1989). 
rule. Information asymmetries, transaction costs, and end-game dilemmas can prevent riders from being extracted. These problems are particularly severe at the close of legislative sessions, when state legislatures operate at a frenetic pace. "It is not unusual to find 30 to 40 percent of all bills passed during a session receiving final approval in the last week before adjournment." 189 In situations like this, riders can survive even under an open rule. ${ }^{190}$

\section{Summary of Riders}

Riders do not result from political bargaining but rather a manipulation of legislative procedures. Notwithstanding its many benefits, the committee system permits legislators to attach unpopular measures to otherwise popular bills. Notwithstanding their many benefits, legislative rules can prevent riders from being excised. This situation is exacerbated by imperfections in the market for votes. The end result is that riders become law, and they move a majority of legislators down their list of preferences.

\section{Public Choice Theory and Political Transparency}

Ensuring that the contents of legislation are comprehensible is a fundamental but sometimes underappreciated ${ }^{191}$ purpose of the single subject rule. This purpose is underpinned by three assumptions: (1) legislators and citizens sometimes do not fully grasp legislation; (2) this information problem can lead to inferior lawmaking, and improving access to information would improve the quality of law; and (3) confining acts to a single subject will help to achieve this result.

With regard to the first assumption, the evidence is pretty clear. When "the legislative juggernaut ... get[s] rolling," legislators often cannot keep track of the details of bills and their implications. ${ }^{192}$ With regard to citizens, there can be little doubt that some legislation is incomprehensible. This may be due to the complex nature of some aspects of public policy, the sheer size

189. KeEFe \& OGUL, supra note 172 , at 266.

190. Cf. Weingast, supra note 188 (explaining that committee proposals in the U.S. Congress enjoy high success rates under open rules because of the restrictions placed on the amendment process by customs, rules of recognition, etc.).

191. Even opinions that discuss the single subject rule at length sometimes fail to recognize this purpose. See, e.g., Porten Sullivan Corp. v. State, 568 A.2d 1111, 1115-22 (Md. 1990).

192. Denning \& Smith, supra note 12, at 958; see also supra note 178. 
of a particular bill, simple (and perhaps rational) ignorance or, more cynically, the efforts of politicians to keep their constituents in the dark.

The second assumption is clearly accurate as well. If lawmakers are unaware of the content of bills, the quality of legislation will decline. They cannot remove riders or vote against unfavorable provisions if they do not know about them. Similarly, if citizens cannot understand legislation, the incentive for legislators to pass self-serving, undesirable laws rises. These ideas are captured by public choice theory, which provides a strong case for transparency in lawmaking.

Representative government can be described as a principal-agent game, where the public is the principal and legislators act as the principal's agents. ${ }^{193}$ The premise of such games is that agents' interests do not automatically align with the principal's, thus, delegating authority to agents entails risks. A solution to the principal-agent problem is to monitor agents' behavior and establish a mechanism for punishing disloyalty. Elections provide such a mechanism. ${ }^{194}$ If citizens base their votes on evaluations of performance, legislators who pass bad laws will face defeat at the polls. ${ }^{195}$ This should lead legislators to behave more responsibly. The trick, then, is the monitoring. Political processes can be opaque, and citizens lack the time and attention for careful oversight. ${ }^{196}$ Any method of making monitoring easier should lead legislators to act in the public interest and pass better laws.

So far, I have argued that legislators and citizens sometimes do not understand legislation, that this ignorance can lead to undesirable laws, and that improving access to information will mitigate this problem. The next issue is whether the single subject rule can be helpful in this regard. (1986).

193. See, e.g., John Ferejohn, Incumbent Performance and Electoral Control, 50 Puв. Сногс 5, 8

194. See generally id. (developing the notion that elections provide a mechanism for penalizing legislators who perform poorly); Robert J. Barro, The Control of Politicians: An Economic Model, 14 PuB. Choice 19 (1973).

195. See Ferejohn, supra note 193, at 7 (citing V.O. Key, JR., The Responsible Electorate: Rationality in Presidential Voting 1936-1960 (1966)); see also Cooter, supra note 149, at 175 ("When voters are well informed, winning elections requires giving the voters what they want."); Alicia Adsera et al., Are You Being Served? Political Accountability and Quality of Government, 19 J.L. Econ. \& ORG. 445 (2003) (providing empirical support for the hypothesis that better monitoring will curb the opportunities for legislators to act self-interestedly and force them to more accurately represent their constituents).

196. See generally Arthur Lupia \& Mathew D. McCubbins, The Democratic Dilemma: Can Citizens Learn What They Need to Know? 205-27 (1998). Because citizens lack the time for careful monitoring, they rely on political cues from other sources, including interest groups and the media. See id. As political transparency improves, these cues will become more accurate and cheaper to acquire. 
Proponents of the rule assume that it can. Confining acts to one subject and requiring their titles to express their contents should make legislation easier to understand. This should help legislators identify and vote against unpopular provisions. It also should make it easier for citizens to monitor their representatives and the policies that they support.

These arguments have intuitive force, but they are too simplistic. When legislators logroll, they exchange their support of one measure for support on another measure. If those measures have to be separated into two bills, legislators who are not privy to the logroll may examine the first bill, fail to perceive the underlying bargain (which they might support), and vote against it. This would not change the outcome; the measures would still be approved by the favorable votes of those who participated in the logroll. But the legislator who erroneously voted against the first provision might regret his decision. He may prefer that his record not include a vote against a provision whose passage was integral to the subsequent implementation of a law he strongly supports. He also would benefit generally from understanding what political deals are unfolding around him. As this scenario demonstrates, allowing several measures to be combined in one act may improve legislators' information by helping them to recognize political bargains and compromises.

For the same reasons, reducing the number of provisions in a bill does not necessarily make it easier for citizens to monitor their representatives. It clouds the tradeoffs their representatives are required to make on a routine basis. To illustrate, assume that San Franciscans strongly support a proposed business practice, A, and mildly approve of another practice, B. Bills that would legalize these practices are pending in the state legislature, but only B will pass on its own merits. The legislator representing San Francisco guarantees that A will pass by trading her vote on measure B, ensuring B's defeat. If bills A and B are voted on separately, San Franciscans will disapprove of their legislator's voting record. They will see that she voted against measure $\mathrm{B}$, which they favor. On the other hand, if the bills can be combined - perhaps into one act that legalizes A and forbids B — citizens are more likely to perceive the underlying bargain. With a combined bill, the legislator can more credibly justify her actions, explaining that she had to sacrifice B to get A, San Franciscans' most preferred alternative. Likewise, citizens - and interest groups, media, and other consumers of political information-can more easily perceive her intentions. ${ }^{197}$ 
Based on this analysis, strict application of the single subject rule may be counterproductive with respect to making legislation and the lawmaking process more transparent. It slices political compromises into discrete frames, simplifying the monitoring of individual bills but obscuring the tradeoffs that underlie them.

\section{Gubernatorial Influence and Legislative Bargains}

Courts tend not to identify a constitutional relationship between the single subject rule and governors' veto power. But, as a practical matter, the two are clearly related: the broader the definition of permissible subjects, the more constrained is the governor's ability to exercise a veto. ${ }^{198}$ This tradeoff between the breadth of acts and executive authority implicates separation of powers concerns. Although public choice theory has much to say about the separation of powers, most of that line of inquiry is beyond the scope of this paper. What is relevant is the role governors play in legislative bargains, as that relates closely to issues of logrolling and riding.

Despite the formal separation of the executive and legislative branches, observers have long recognized that governors play an indirect but prominent role in lawmaking. ${ }^{199}$ This can be attributed to several factors. First, unlike legislators, governors represent their entire states, putting them in the best position to identify the needs of the whole electorate. ${ }^{200}$ This can help them set the legislative agenda and, through the prestige of the office, garner support for their proposals. ${ }^{201}$ Second, governors usually exert strong influence on their state political parties. ${ }^{202}$ Legislators who belong to the governor's party can guide the governor's favored bills through the legislature, particularly if they occupy leadership positions. ${ }^{203}$ Third, governors propose the state budget, which is the "single most important document in determining the policy initiatives and goals of government."204 Fourth, and most

198. See Harbor v. Deukmejian, 742 P.2d 1290, 1299 (Cal. 1987).

199. See, e.g., Leslie Lipson, The American Governor: From Figurehead To Leader 52-63, 206-22 (1939); E. Lee Bernick \& Charles W. Wiggins, Executive-Legislative Relations: The Governor's Role as Chief Legislator, in Gubernator ial Leadership and State Policy 73 (Eric B. Herzik \& Brent W. Brown eds., 1991); see also Sarah McCally Morehouse, The Gover nor as Party Leader 204 (1998) ("The governor is assumed to be part of the legislative leadership.").

200. See Lipson, supra note 199, at 53.

201. See Bernick \& Wiggins, supra note 199 , at $76,81$.

202. See Lipson, supra note 199, at 57; Morehouse, supra note 199, at 204-05.

203. See Morehouse, supra note 199, at 204-05.

204. Bernick \& Wiggins, supra note 199 , at 77. 
significantly, governors possess the veto, which can be used as a bargaining tool to secure legislative support. ${ }^{205}$ Unless enough legislators support a bill to override a veto, the bill must, on balance, be satisfactory to the executive. For these reasons and many others, the seal between governors and legislatures is less than tight.

Gubernatorial influence in the legislative process can give rise to the activities that are condemned by courts interpreting the single subject rule. To illustrate, assume that a governor publicly committed herself to passing a provision, A, that most legislators oppose. She could use her influence to combine that measure with others into one bill that would receive majority support. Assuming that legislators who oppose but nevertheless vote for A receive something for their sacrifice, this would be a classic case of logrolling. If, on the other hand, the governor did not organize a broad bargain but rather convinced a committee member to add A to another bill, A would be a rider.

Several observations can be drawn from this discussion. For one, instances of logrolling and riding may not solely be the work of the legislature. Governors can play an indirect role in these practices, so courts may not wish to confine their wrath to the legislative branch. Second, courts should be cautious about using the single subject rule to strengthen the veto power. The executive has other means of affecting legislative outcomes. Third, and most importantly, strict interpretations of the single subject rule strengthen governors' veto power but do not necessarily increase executive authority overall. A stringent reading of the rule would force legislators to pass narrow bills, each of which would be subject to the governor's veto. This would appear to strengthen the governor's hand. But that same stringent interpretation would restrict the governor's ability to orchestrate legislative bargains. This would be especially true among unstable coalitions-for example, when the legislature is fractured, or the governor and legislative majority are from different political parties. In situations like those, would-be vote traders may lack the trust to logroll across separate acts. This could prevent the governor from enacting legislation he favors. Consequently, a strict reading of the single subject rule does not necessarily augment net executive power.

The approach to single subject adjudication advocated in Part IV does not discuss cases that are premised on erosion of the gubernatorial veto. Such cases are different enough from the logrolling, rider, and transparency cases

205. Lipson, supra note 199, at 57. The President retains this same leverage. See Charles M. Cameron, Veto Bargaining: Presidents and the Politics of Negative Power (2000). 
that they deserve a separate treatment, and that is beyond the scope of this paper. Nevertheless, the analysis in this section may aid courts in scrutinizing some of the arguments that arise in these cases.

\section{A New Approach to Single Subject Adjudication}

As Part I made clear, the single subject rule has generated a substantial amount of litigation over the last 150 years, including cases on important, visible public issues. As Part II illustrated, single subject jurisprudence is murky; this is due in large part to the vagueness of the rule itself. As Part III showed, the historical purposes of the rule do not necessarily rest on firm analytical footing. In light of these observations, courts, legislators, and citizens alike would benefit from a more cogent approach to the single subject rule. In this Part, I offer such an approach.

Before proceeding, I should emphasize one point. Although this proposal calls for a new approach to single subject disputes, its aims are consistent with what many courts already are attempting, at least implicitly, to achieve. This makes the proposal relatively easy to implement in many states: it does not introduce new jurisprudence so much as clarify and re-conceptualize existing precedent. With that said, some courts may find the proposed changes too dramatic to be adopted outright. In that case, a state constitutional amendment may be required. In any event, my goal is to flag issues that are relevant in single subject disputes and develop a new framework for resolving them, not identify the precise means through which these ideas can be implemented.

\section{A. Courts Should Condone Logrolling}

As discussed in Part III, logrolling is tantamount to vote trading, and every instance of it improves the well being of a majority of legislators. Legislators not involved in a given bargain may be left worse off because of it. ${ }^{206}$ However, those legislators may be able to improve their positions through other deals. One of the virtues of logrolling is that it encourages the formation of coalitions based not on ideology but rather on political capital.

206. Note, however, that those parties may have been left out of the deal by their own choosing. See Clayton P. Gillette, Expropriation and Institutional Design in State and Local Government Law, 80 VA. L. REV. 625, 637 n.35 (1994) ("All representatives have an opportunity to logroll, so the fact that representative A demands less for his vote and thus participates in the logroll that adversely affects constituents of representative $\mathrm{B}$, who demanded more for her vote, does not necessarily mean that representative B was excluded."). 
So a legislator who is in the minority politically-and who thus loses out on some legislation - nevertheless can join and benefit from bargains with other factions. ${ }^{207}$ But this does not prove that logrolling is socially beneficial. Even if every legislator benefits at some point from logrolling, the practice is still undesirable if, on the whole, the losers lose more than the winners win.

If logrolling were always detrimental, then a flat ban on it would be sensible. If logrolling were always beneficial, then a ban would be misplaced. In reality, logrolling is probably in between. Sometimes it helps, and sometimes it hurts. This would not present a problem if courts had perfect information and judicial review was costless. Judges could distinguish between beneficial and harmful logrolls and only strike down the latter. Time spent on filtering logrolls would not be socially costly. Of course, these conditions do not hold. An act that looks harmful may be integral to the subsequent passage of an act that generates substantial social returns. ${ }^{208}$ Striking down the first act could scuttle the deal. Alternatively, legislation that seems sound could, due to shifts in the many variables that affect public policy, yield social losses. Indeed, the very terms beneficial and harmful imply a metric for sorting good laws from bad ones. But is that metric based on utility maximization, satisfaction of preferences, equity, efficiency, or something else? And over what timeframe would the metric be calculated? Because of these intractable information problems, there is no reason to suppose that courts can accurately distinguish between beneficial and detrimental logrolls. Thus, there is no reason to suppose that case-by-case judicial review will produce a social benefit. ${ }^{209}$

The key, then, is to adopt a presumption about logrolling that minimizes overall social costs. ${ }^{210}$ If, on average, logrolling produces a social benefit, broadly defined, then courts should presume that every instance of logrolling is allowable, since they cannot tell which logrolls produce a benefit and which do not. ${ }^{211}$ If, on average, logrolling causes harm, and if the benefits of judicial review outweigh the costs, then logrolling should be banned, and courts should review legislation and strike down logrolled bills. ${ }^{212}$

207. See Eskridge, Frickey \& Garrett, supra note 18, at 172 (arguing that logrolling allows minority legislators to obtain government ben efits for marginalized groups); Gillette, supra note 206, at 636 ("[B]ecause coalition building will often require an effective logroll, minority representation in legislative dealmaking should be enhanced by vote trading.").

208. See Gillette, supra note 206, at 649.

209. See id.

210. See id.

211. See id. at 650 .

212. See id. 
I argue that courts should adopt a presumption in favor of logrolling. They should assume that logrolling on the whole is socially beneficial, and therefore individual logrolled bills are constitutionally sound.

To make my case, consider first the limited effects of a presumption against logrolling. Before striking anything down, courts would have to identify instances of logrolling. If the logrolling took place within a single bill, they may have some success. If, however, the logrolling took place across separate bills, then the single subject rule would provide no guidance. Each individual bill would embrace one subject. Stable legislative coalitions could logroll across separate bills, and judges could not use the rule to stop them.

If same-bill logrolls are usually harmful, then invalidating them would be sensible, even if they only represent a fraction of all logrolls. If, however, same-bill logrolls tend to be beneficial, then invalidating them would leave society worse off. Professor Clayton Gillette provides a reason to believe that same-bill logrolls will often be beneficial. ${ }^{213}$ Legislators orchestrating the most egregious trades have a strong incentive to spread them across separate bills. Doing so makes it harder for the public to uncover the nefarious arrangement. Legislators operating for the public good would be less secretive about their bargain and more likely to present it as a single measure. Ironically, these beneficial, same-bill logrolls would get struck down. ${ }^{214}$ According to this argument, the single subject rule will tend to strike down those logrolls that are the most beneficial.

So far the discussion has assumed that the single subject rule can only be used to attack same-bill logrolls. But if constitutional revision is a possibility, the rule could be expanded to ban all logrolling, irrespective of whether it takes place in a single bill or across separate ones. In light of Gillette's argument, the rule could even be tailored to ban only separate-bill logrolls, under the assumption that they are harmful and same-bill logrolls are not. For these reasons, my argument must rest on more than theoretical differences between same-bill and separate-bill logrolls. I provide more general arguments in favor of logrolling in the following paragraphs.

Consider the incentives of legislators. Legislators can be expected to recognize whether logrolling systematically harms them. ${ }^{215}$ Information gaps

213. See id. at 663 .

214. See id.

215. See Eric M. Uslaner \& J. Ronnie Davis, The Paradox of Vote Trading: Effects of Decision Rules and Voting Strategies on Externalities, 69 AM. PoL. SCI. Rev. 929, 936-37 (1975) (arguing that rational legislators will learn when to stop trading and thus avoid the potentially harmful effects of 
may prevent them from knowing whether a given sequence of trades will, on the whole, make them better or worse off. But over entire legislative sessions and, in the case of many politicians, multiple terms, rational legislators should be able to discern whether logrolling is beneficial. ${ }^{216}$ If it is not, we would expect them to ban the practice or take other steps to make it less harmful. It is hard to imagine legislators permitting an institutional arrangement that works against their self interest to endure. ${ }^{217}$

One could respond to this claim in the following way: the failure of legislators to prevent logrolling does not indicate support for the practice if collective action problems are present. To illustrate by example, assume that during a single year all legislators gain an average of 5 utility from participating in some logrolls but lose an average of 6 utility from being excluded from other logrolls and bearing costs associated with those trades. Thus, logrolling is harmful to every legislator; on net, the practice leaves all legislators with -1 utility. However, no individual legislator has an incentive to stop logrolling - doing so would lower that legislator's utility from -1 to -6. She would still bear the costs of logrolling but not glean any benefits. In such a circumstance, legislators would continue to logroll even though they oppose and are harmed by the practice. ${ }^{218}$

Collective action problems are real, so this argument has force. However, such problems probably do not grip most legislatures most of the time. If legislators can cooperate, they can resolve collective action problems and avoid the situation described above. Logrolling implies cooperation. To argue that legislators can cooperate to logroll but not to stop logrolling, even though doing so would benefit them, is dubious. ${ }^{219}$ More generally, democratic governance presupposes that measures approved by a majority are good for society as a whole. Majority-approved measures that turn out to be harmful in the aggregate are exceptional. To assume without evidence that,

logrolling without the cooperation of all parties).

216. See id. at 937 ("It is not terribly difficult for a rational legislator to realize when to stop trading and when the Pareto optimal position has been reached ....").

217. Cf. FARBER \& Frickey, supra note 149, at 53 (noting that "[n]atural selection" would weed out a legislature that did not develop checks on legislative cycling and other occurrences that work against the self-interest of legislators).

218. See supra note 161

219. To be clear, I am not claiming that legislators cannot execute inefficient logrolls-vote trades that cause more harm than good. They can. See supra Part III.A. Rather, my claim is that when the negative effects of such logrolls are spread systematically across a majority of legislators, and therefore a majority would like to stop logrolling from taking place, collective action problems are unlikely to prevent them from achieving that goal. 
because of collective action problems or other issues, majority-supported logrolls are usually harmful would permit the exception to swallow the rule.

If these arguments are correct, then legislators will ban logrolling if it systematically harms a majority of them. Does the existence of the single subject rule imply that legislators are harmed by logrolling and seek to prevent it? After all, legislators created the rule in the first place. The answer to this is no. If legislators really sought to eliminate logrolling, they would ban it outright, not adopt a vague rule that attacks logrolling indirectly. Moreover, the historical rationale for the single subject rule seems to be directed at preventing riding and deception, not logrolling per se. ${ }^{220}$ For these reasons, courts are not required to invalidate all logrolls, and many judges recognize this. ${ }^{221}$

Beyond the gains it yields to legislators, logrolling smoothes the edges of the lawmaking framework. As discussed in Part III, most legislatures are divided into committees with near-exclusive gatekeeping authority. This arrangement produces a number of benefits, but it also has costs, including this one: committees can close the gates on bills that fall within their jurisdiction when, despite promising substantial benefits to the rest of the legislature and to society more generally, they are disagreeable to the committee members. For example, a situation could arise in which a measure A is supported by most legislators and citizens but not the members of the committee to which $\mathrm{A}$ is assigned. If logrolling is forbidden, the committee cannot be induced to open the gates and report $\mathrm{A}$ to the full legislature. ${ }^{22}$ Legislators cannot offer the committee members support on other measures in exchange for an opportunity to vote on A. By contrast, if logrolling is allowed, legislators can strike a deal. The committee will report out A in exchange for support on another measure it holds dear. Logrolling in this scenario preserves the advantages of the committee system and reduces one of the costs. It prevents gridlock on important issues whenever the preferences of a committee diverge from the preferences of the full legislature. ${ }^{223}$

220. See, e.g., supra text accompanying notes 35 and 37; see also infra note 230 .

221. Despite the rhetoric, many judges do not understand the single subject rule or require them to stamp out all or even most political compromises. See, e.g., State ex rel. Ohio AFL-CIO v. Voinovich, 631 N.E.2d 582, 596 (Ohio 1994) (Douglas, J., concurring) ("The General Assembly, and properly so, engages in 'logrolling' much of the time. The only 'logrolling' that is constitutionally proscribed is that which results in an Act violating the one-subject rule ....") (emphasis omitted).

222. Presumably, the full legislature could pry open the gates, but this would be politically costly.

223. For an overview of the representativeness of committees in Congress, see KeEFE \& OGUL, supra note 172 , at $195-97$. 
Even if logrolling tends to benefit legislators and grease the hinges of their organizational framework, the practice may nevertheless harm society. Politicians respond to organized interest groups within their constituencies. ${ }^{224}$ If legislators logroll to help those groups, legislators may profit - through campaign contributions and other favors - while the rest of the legislator's constituents and, on balance, society as a whole suffers. ${ }^{225}$

While legislators almost certainly respond more to organized groups than to scattered individuals, they still need to garner enough votes to win elections. Doing so requires them to take actions that benefit most of their constituents. ${ }^{226}$ Thus, legislators generally can only execute self-serving but socially harmful logrolls if they can keep those logrolls out of the public eye. Such deception may be possible when the policy matter is complicated or obscure. It would also help if the legislative coalition was stable, and the logroll could be spread subtly across multiple bills. But when its social implications are substantial and plainly negative, a logroll is likely to attract considerable publicity. This may be true even if the logroll's components are distributed over separate acts. So for legislators to engage in self-serving logrolling that they know is harmful, the aggregate social loss must be relatively modest. ${ }^{227}$

Based on this analysis, the average social loss from harmful instances of logrolling should be modest. By contrast, the average social gain from beneficial instances of logrolling could be substantial. After all, there is no

Committees are not the only roadblocks to the passage of popular legislation. Filibusters and other procedural mechanisms permit a minority to stand in the way of majority-supported bills. Logrolling provides a method of navigating all such roadblocks.

224. See generally FARBER \& FrICKEY, supra note 149, at 12-37.

225. The budget process in Congress often provides a precise example of this type of logrolling. Legislators bargain hard to bring specific expenditures to their states, and these expenditures are financed with broad taxes that harm all taxpayers. The aggregate harm to taxpayers may exceed the benefit to recipients of specific expenditures. This is especially true when this logic leads to rampant expenditures and significant budget deficits. Logrolling of this sort poses less of a risk at the state level. Forty-nine states, including every state with a single subject rule, have some sort of balanced budget requirement. See Ronald K. Snell, State Balanced Budget Requirements: Provisions and Practice (2004), available at http://www.ncsl.org/programs/fiscal/balbuda.htm\#t1 (last visited Mar. 6, 2006); see also Henning Bohn \& Robert P. Inman, Balanced Budget Rules and Public Deficits: Evidence from the U.S. States 1-7 (Nat'1 Bureau of Econ. Research, Working Paper 5533, 1996), available at http://www.nber.org/ papers/w5533.pdf (last visited Mar. 6, 2006) (reporting that at least some of these balanced budget requirements are effective).

226. See Weingast \& Marshall, supra note 187, at 137 (stating that electoral competition induces representatives to act in the interests of their constituents and citing several empirical studies of the U.S. Congress finding that constituents' interests systematically influence voting).

227. See Gillette, supra note 206, at 652. 
shame in forging a popular compromise, and no limit on social gains that politicians dare not pass. The question, then, is how frequently harmful and beneficial logrolls arise. If there are equal numbers of both, or more beneficial logrolls than harmful ones, the average logroll should be beneficial. If there are more harmful logrolls than beneficial ones, the average logroll may be harmful. The answer to this question turns on political transparency and the transaction costs of legislative bargaining. The more transparent the lawmaking process, the more representative legislators will be of broad crosssections of their constituents, not just narrow interest groups. Otherwise, they will face defeat at the polls. And the more representative legislators are of large numbers of constituents, the more logrolls will tend to be beneficial — not just to legislators, but to society as well. ${ }^{228}$ Likewise, as the transaction costs of bargaining fall, logrolls will more often be beneficial. ${ }^{229}$

Whether a given legislature is so transparent and the bargaining costs are so low that harmful logrolls are relatively uncommon and thus average logrolls are beneficial is hard to know. What is clear is the direction of causality - lack of transparency and high bargaining costs should lead to more harmful logrolls. Banning logrolling will not unwind this chain. Because enforcement of anti-logrolling laws is necessarily imperfect, legislators will continue to trade votes as long as the expected payoff from doing so is higher than the expected payoff from refraining. But with a ban in place, they will refuse to acknowledge that they trade, and they will have incentives to spread logrolls across as many bills as possible to minimize the risk of detection. This obviously cuts against transparency. In contrast, permitting logrolling will allow legislators to speak openly about political compromises and reduce the incentive to tuck their bargains piecemeal into the folds of several bills. Likewise, allowing logrolling will give legislators a stronger incentive to try to lower the costs of bargaining to maximize the cooperative potential of the legislative process.

Granted, condoning vote trading would permit some harmful logrolls to succeed where they otherwise would have failed. Legislators who lacked the trust to spread a nefarious logroll across separate acts (and thus try to sidestep a logrolling ban) could include their bargain in a single bill under a regime of legal vote trading. But harmful logrolls of this sort would be the ones most likely to come to light. And legalized vote trading would permit more beneficial logrolls to succeed as well. 
A final issue bears mentioning. Despite my arguments, one may conclude that logrolling tends to be socially harmful and should be banned. However, this does not lead inevitably to the conclusion that courts should use the single subject rule or some other device to enforce such a ban. Judicial review is costly, and the costs incurred in fighting logrolls may overwhelm the benefits. Courts can only address a certain number of cases in a given period, and if logrolling cases clutter the dockets, other important cases will go unaddressed. In addition, judicial review theoretically raises the transaction costs of passing legislation. To guard against judicial error and the invalidation of nonlogrolled bills, legislators would have an incentive to pass narrower legislation. Passing narrower bills would raise transaction costs, since every bill has to undergo a separate deliberation and vote. Because legislators can only deal with a limited number of issues in a given session, these transaction costs could prevent pressing laws from being enacted. Taken together, these costs could be substantial.

For all of the reasons suggested, courts should openly condone the practice of logrolling. ${ }^{230}$ This would save judges from puzzling over whether

230. There is a potential impediment to this proposal: it appears to run contrary to decades of single subject jurisprudence. Assuming constitutional revision is not an option, there is nevertheless an opening for judges to implement the ideas developed here without appearing unfaithful to precedent or original intent.

First, notwithstanding the rhetoric, I do not believe that most judges understand the rule to require them to strike down all logrolls. See, e.g., supra note 221. Rather, I suspect that courts worry more about riders. The analysis in this article may refine their intuitions and make clear that riders are distinct from logrolls and the real focus of their enforcement efforts.

Second, with respect to originalintent, many of the earliest single subject opinions suggest that riding and opaqueness in lawmaking were the primary targets of the rule, not logrolling. See, e.g., State v. Harrison, 11 La. Ann. 722, 722-23 (1856) ("Chief Justice Eustis, who was a prominent member of the Convention which formed the Constitution of 1845 , has given us (in the case of Walker v. Caldwell, 4 La. Ann. 297 [La. 1849]) the following reasons for the enactment of the [the single subject rule]: ... The title of a law often afforded no clue to its contents; important general provisions were found placed in Acts private or local in their operation; provisions concerning matters of practice or judicial proceedings were, sometimes, in the same statute with matters entirely foreign to them. It was to prevent such anomalies, [that the rule was adopted].”) (opaqueness); Davis v. State, 7 Md. 151, 160 (1854) (“A practice had crept into our system of legislation, of engrafting, upon subjects of great public benefit and importance, for local or selfish purposes, foreign and often pernicious matters, and rather than endanger the main subject, or for the purpose of securing new strength for it, members were often induced to sanction and actually vote for such provisions, which if they were offered as independent subjects, would never have received their support.") (riding); see also State ex rel. Weirv. County Judge of Davis County, 2 Clarke 280, 282 (Iowa 1855) ("The intent of this provision of the constitution was, to prevent the union, in the same act, of incongruous matter, and of objects having no connection, no relation. And with this, it was designed to prevent surprise in legislation, by having matter of one nature embraced in a bill whose title expressed another.")(opaqueness); Ramsey County Bd. of Supervisors v. Heenan, 2 Minn. 330, 336 (1858) (“"A] very vicious system prevailed of inserting matter in acts which was entirely foreign to that expressed in the title, and by this means 
securing the passage of laws which would never have received the sanction of the legislature, had the members known the contents of the act; it was to prevent frauds of this nature that [the single subject rule] was passed ....") (riding and opaqueness); Allegheny County Home's Case, 77 Pa. 77, 80 (1874) (“The constitutional provision that a law shall not embrace more than one subject, which shall be expressed in the title, merely requires that the title fairly give notice of the subject of the act, so as reasonably to lead to an inquiry into [its] body ....”) (opaqueness); Tadlock v. Eccles, 20 Tex. 782, 792-93 (1858) ("The intention doubtless was, to prevent embracing in an act, having one ostensible object, provisions having no relevancy to that object, but really designed to effectuate other and wholly different objects, and thus to conceal and disguise the real object proposed by the provisions of an act under a false or deceptive title.") (opaqueness); Cutlip v. Sheriff of Calhoun County, 3 W. Va. 588, 590 (1869) ("The object of this provision was to guard against the enactment of laws by ... including in an act for one purpose, which was stated in its title, other and different objects, not so stated, and of which nothing was often known save by a few interested in the bill. ... Another important object was to secure a fair and impartial consideration of each subject by making it to stand or fall on its merits, instead of having it carried against the wishes of the majority, often by having it tacked to some important measure it might be difficult or disastrous to defeat.") (opaqueness and riding; logrolling can never happen against the wishes of the majority).

Even courts that immediately described logrolling as a target of the rule often were referring to riding. See, e.g., Beebe v. State, 6 Ind. 501, 533 (1855) (“[B]ills were sometimes passed . . by securing a combination of interests, when neither of the measures could have been adopted upon its own merits.... In this way frauds and impositions were sometimes practiced, and there is a notable case shown by the journals, in which a large appropriation of money for the construction of a turnpike was incorporated into a bill for establishing a highway of no public concern, which was not discovered until the bill had passed both houses. To remedy these evils [the single subject rule was enacted].”) (emphasis added). The italicized text describes riding, not logrolling. Logrolling requires a majority of legislators to agree, explicitly or implicitly, to a trade. Therefore, a logroll could not be opposed and undiscovered by so many legislators, while a rider could.

Two states, Michigan and New York, made clear early on that logrolling as defined in this paper was to be halted by the rule. See People v. Collins, 3 Mich. 343 (1854); Conner v. City of New York, 5 N.Y. 285 (1851). But see Sun Mut. Ins. Co. v. City of New York, 8 N.Y. 241, 252 (1853) ("The purpose of the [single subject rule in New York] was, that neither the members of the legislature, nor the public, should be misled by the title ...."). Conner was influential; other state courts cited it when they sought guidance on the rule and declared that it forbade logrolling. See, e.g., Durkee v. City of Janesville, 26 Wis. 697, 701 (1870); see also O’Leary v. County of Cook, 28 Ill. 534, 542 (1862) (Breese, J., dissenting) (arguing that the purpose of the rule is to stop logrolling as described in Conner); State v. Harrison, $11 \mathrm{La}$. Ann. 722, 726 (La. 1856) (Spofford, J., dissenting) (same). Collins was even more important, because it set the stage for People ex rel. Drake v. Mahaney, 13 Mich. 481, 494-95 (1865), where Justice Cooley of the Michigan Supreme Court embraced the rule's anti-logrolling rationale. Three years later, he released his classic treatise. See Thomas M. Cooley, Treatise on the Constitutional Limitations Which Rest upon the Legislative Power of the States of the American Union (Little, Brown, and Co. ed., 1868). After citing opinions of several state supreme courts, including Drake, he concluded that preventing logrolling was one of the primary purposes of the rule, even though Drake was the only opinion listed that actually stated this. See id. at 141-44.

This treatise and its subsequent editions had a profound effect on single subject jurisprudence; judges in nearly every state with the rule looked to Cooley for guidance on its purposes. Hence, the anti-logrolling rationale spread, even if stopping logrolling was not what the constitutional framers in a given state desired.

The point of this cursory historical analysis is that in the formative years of single subject jurisprudence, courts were uncertain of the rule's purposes. Some cited logrolling, but many others focused on transparency and riding. Cooley's treatise changed this by essentially nationalizing an understanding of the rule that at the time only prevailed in Michigan and, at most, a handful of other states. Because of 
all provisions of a bill are "reasonably germane" to one another. They could simply assume that a bill's provisions, no matter how disparate, belong together because they are logically connected in legislator's minds or because they resulted from a successful logroll. It would also widen the sphere of legislative cooperation. Legislators who have no interest in subjects related to provision A nevertheless could participate in a logroll by proposing the addition of an unrelated provision, B. This would give legislators more leverage to bargain and lead to broader and more efficient logrolling. ${ }^{231}$

The public choice approach lays the foundation for a definition of a single subject. A bill can be said to embrace but one subject when all of its components command majority support due to their individual merits or legislative bargaining. If a bill combines several popular measures in order to save legislative transaction costs, courts should not interfere, and they would not under this definition. If a bill's provisions resulted from a logroll, courts should presume that the arrangement was beneficial and, under this definition, they would.

\section{B. Courts Should Invalidate Bills Containing Riders}

When a bill containing a rider is passed, a majority of legislators is left worse off. They oppose the rider on its face and received nothing in exchange for their support of it. This does not imply that every rider is socially harmful. As discussed in Part III, a rider produces a net benefit when the utility gains to its supporters outweigh the losses to its opponents. ${ }^{232}$ So whether a given rider is socially beneficial is an empirical question.

As with logrolling, courts cannot possibly filter beneficial riders from harmful ones. Doing so would require, among other things, a metric for determining social effects and an agreed upon timeframe over which to measure them. The proper course, then, is to adopt a presumption about riders that minimizes social costs and apply it uniformly to every bill. If riding tends to be beneficial, courts should condone it in every case. If riding is usually

this, some contemporary courts may be able to move away from the rule's anti-logrolling rationale without clashing with the original purposes of the rule in their states.

231. Cf. COOTER, supra note 149 , at 54 ("In economics and politics, the widest sphere of cooperation affords the greatest opportunity to satisfy peoples' preferences ....").

232. By opponents I mean those legislators who vote against the bill with the rider attached. The majority who votes for the bill with the rider must reap a benefit, however minor, otherwise they would prefer the status quo. 
harmful, and if the benefits of judicial review outweigh the costs, then it should be prohibited.

I propose that courts adopt a presumption against riding. Every bill containing a rider should be condemned for violating the single subject rule.

The case against riders is straightforward. As discussed, a majority of legislators opposes every rider that gets passed. ${ }^{233}$ Despite the theoretical ambiguity, this suggests that in practice riders will tend to cause more harm than good - or at least lead to suboptimal outcomes. More importantly, condoning riders would set a dangerous precedent. It would discourage legislators from compromising, which is costly when it requires them to moderate their positions and trade away votes, and encourage them to ride their favored provisions on popular bills. Surely a system that provides legislators with incentives to bargain and compromise will produce better outcomes than one that encourages them to sneak unpopular provisions into bills and make take-it-or-leave-it offers. For these reasons, I conclude that riding is socially harmful.

This argument begs the following question: if riding is so damaging, why don't legislators ban it themselves? I have several theories. First, legislators may have sought to ban it by adopting the single subject rule. As discussed, early cases suggest that riders were the primary target of the rule in many states. ${ }^{234}$ Of course, this argument is unconvincing insofar as the rule is vague and riders are not directly prohibited. A second explanation is that efforts to ban riding face an insurmountable hurdle: any ban would have to be approved by the chair of the relevant committee and other veto players, the precise individuals who are capable of attaching riders and taking advantage of the practice. A final theory is that a majority of legislators actually benefits from riding. This could happen where, for example, preferred riders bring concentrated benefits to legislators' districts while the riders they oppose spread costs across their own and all other districts. ${ }^{235}$ Such an arrangement may not be financially beneficial — any pecuniary gains from a legislator's preferred rider may be outweighed by the taxes his constituents have to pay to fund the unfavorable riders. Likewise, this arrangement is unlikely to

235. At its worst, logrolling can take on this same form: legislators trade votes to bring focused benefits to their districts and impose diffuse costs on all other districts. Such logrolling may often - but not always - be negative-sum in a financial sense. To illustrate the exception, vote trades that bring federal funds to a district for a project that has substantial positive externalities may, over time, be economically efficient. Again, distinguishing negative-sum and positive-sum logrolls is infeasible, so courts should presume that all logrolls are beneficial. 
improve the overall mix of policies from a given legislator's perspective-for every favorable policy he enacts by rider he has to deal with other unfavorable ones, some of which he may vigorously oppose. But this arrangement could be politically lucrative. Legislators could claim credit among their constituents for the passage of preferred riders and blame, honestly and justifiably, the "system" for facilitating passage of unfavorable riders. ${ }^{236}$ Unlike logrolling, which requires legislators to sully their records by agreeing to vote for some measures they and their constituents oppose, riding permits politicians to keep their hands clean.

None of these theories supports a presumption in favor of riding. Of course, the theories may be wrong-perhaps legislators and most of their constituents, for indeterminate reasons, do benefit from riding. But without evidence or even a theory for why this would be so, and in light of the democratic rule-of-thumb that minorities generally should not frustrate majorities, recourse to my original argument is apt: a practice that always makes a majority of legislators worse off and provides incentives to be obstinate rather than compromising should be prohibited.

A prohibition on riders will only be effective if courts can identify them and root them out. The traditional single subject tests are unhelpful in this regard. Courts need a more sophisticated approach to distinguish riders from logrolls, and I propose one here.

Consider first a world in which courts have perfect information about legislators' voting preferences. This is less restrictive than assuming that courts can filter beneficial logrolls and riders from harmful ones; it does not require knowledge of the intensity of preferences or the social effects of legislation over time. Still, it is unrealistic, and I will relax it in a moment.

Armed with perfect information, courts could follow these steps to identify riders. First, they would separate a bill into its functionally related components. ${ }^{237}$ A functionally related component is one whose provisions all

236. For a possible example of this type of behavior in the U.S. Congress, see Carl Hulse, Foe of Earmarks has a Pet Cause of His Own, N.Y. Times, Feb. 18, 2006 (reporting that Senator John McCain, an outspoken critic of spending riders and a sponsor of legislation intended to stop them, is pushing a "parochial spending request" that would channel federal funds to a project in his home state).

237. This notion of functional relationships is drawn from a proposal raised by Justice Manuel of the California Supreme Court in the context of initiatives. See Schmitz v. Younger, 577 P.2d 652, 656 (Cal. 1978) (Manuel, J., dissenting). Dividing bills into functionally related components prevents provisions that complement one another - for example, a tax measure and a spending measure, neither of which is valuable on its own but both of which are very valuable together-from failing the test.

In a second paper on this topic, the notion of a functional relationship is clarified and refined by using the concept of non-separable preferences. See Cooter \& Gilbert, supra note 33. 
rely on one another to be effective. To illustrate, if a measure A collects revenues for expenditure on a measure $\mathrm{B}$, the measures have a functional relationship and collectively should be treated as one component of the bill. A measure $\mathrm{C}$ that is topically related to A and B but can be substantially effective without them would be a separate component. Once all of the functionally related components were identified, a court would ask this question about each one: assuming all legislators adhere to their promises, if this component were removed and voted upon separately, would it receive majority support? If the answer is no, the component is a rider, and the bill violates the single subject rule.

The intuition behind this test runs as follows. There are three types of provisions in any bill that receives majority support-popular ones that would pass on their own merits, provisions that are being logrolled, and riders. Popular provisions would get majority support regardless of whether they were coupled with other measures, so the test would never mistakenly implicate them. Similarly, the test would not mistake a logrolled component for a rider. Legislators logroll to garner majority support for their favored measures. To ensure that they receive such support, they must promise to give up their votes on other measures. If they follow through on their promises, they will vote for all measures involved in the trade. As a result, all logrolled components would receive majority support, and this is true regardless of whether the components were voted upon in the same or separate bills. In contrast, more legislators oppose riders than favor them, and no one promises, explicitly or implicitly, to vote for a rider. They are forced to do so by legislative rules and procedures. If a rider were voted upon separately, it would not receive majority support. ${ }^{238}$

238. Two examples will clarify this test. Assume first that 100 legislators are deliberating over two unrelated measures, A and B. A is supported by legislators 1 to 40 and opposed by everyone else. B is supported by legislators 41 to 80 and opposed by everyone else. Now assume that A and B are logrolled into one bill and that legislators 1 to 80 support this exchange (the gain to each legislator from enacting his favored provision outweighs the loss from enacting the unfavorable provision). Now imagine that the committee with jurisdiction over A and B consists of legislators 1 to 5 and 41 to 44 . These nine legislators support measure C; all 89 other legislators oppose it. Suppose the committee attaches $\mathrm{C}$ to $\mathrm{AB}$ and reports the bill to the legislature, where $\mathrm{ABC}$ passes with fifty-five votes (for legislators 1 to 20,41 to 65 , and 81 to $90, \mathrm{ABC}$ yields a net benefit). If A were removed and voted upon separately, and if all legislators kept their promises, A would still command eighty votes-legislators 1 to 80 would faithfully vote for A as part of their agreement (which was implicitly contingent on nothing else getting attached to $\mathrm{AB}$ ). The same would hold for B. C, however, would not receive majority support. Only nine legislators ( 1 to 5 and 41 to 44) would vote for it as a standalone measure. It only passed in the first place because, despite their disdain for it, a sufficient number of supporters of $\mathrm{AB}$ felt that $\mathrm{ABC}$ was superior to nothing. Those legislators did not promise to support $\mathrm{C}$ and would not do so if they could vote on $\mathrm{A}, \mathrm{B}$, and $\mathrm{C}$ in piecemeal 
This test offers a framework for parsing riders from logrolls and independently popular measures. Of course, applying the test is considerably more difficult than articulating it. Determining which components have a functional relationship would involve some discretion. And courts cannot determine with precision how faithful legislators would have voted if a given bill were divided into separate components. This is particularly true given that legislators often have incentives to conceal their true preferences. Nevertheless, the test has practical merit. Courts need not be absolutely accurate in every case. As long as they can identify some riders without incurring too many costs - by, for example, striking down popular or logrolled legislation - then judicial review is worthwhile. I believe they can glean enough information to do so.

First, courts could look to the legislative process that produced the bill. Provisions added on the floor could not be riders since they received majority support from the full legislature. Thus, judicial analysis would be limited to those provisions that were attached to the bill before it emerged from committee. Legislation that was adopted under a relatively closed rule should be subject to greater scrutiny than legislation passed with a relatively open rule. In making this determination, courts should consider how many amendments were allowed on the floor, how many non-committee members were recognized, and whether amendments with respect to any particular provisions in the bill were restricted. In general, more floor debate should correspond to less judicial scrutiny.

Second, courts could consider the legislative history of the bill, if available. ${ }^{239}$ The focus should not be on the records of the bill's drafters but

fashion. The test would properly identify $\mathrm{C}$ as a rider. Note that the committee has an incentive to report out $\mathrm{AB}$ (because they support the logroll) even if they know that $\mathrm{C}$ will be eliminated because it is a rider.

Now assume that legislators 1 to 40 still support A, legislators 41 to 80 still support B, and they all implicitly agree to logroll the two provisions. This time the committee with jurisdiction over A and B consists of legislators 81 to 89 . These nine legislators are opposed to A and B but support measure C. They are the only legislators who like $\mathrm{C}$. In exchange for reporting out $\mathrm{A}$ and $\mathrm{B}$, the committee extracts promises from legislators 1 to 80 to vote for $\mathrm{C}$. If $\mathrm{A}$ and $\mathrm{B}$ were removed and voted upon separately, and if all legislators kept their promises, they would both receive votes from legislators 1 to 80 (legislators 81 to 89 did not technically agree to vote for A and B, they just agreed to open the gates and report them to the full legislature). If $\mathrm{C}$ were removed and voted upon separately, it would receive votes from legislators 1 to 89 . Despite its individual unpopularity, $\mathrm{C}$ is a bargained for provision, not a rider, and the test would properly identify it as part of a logroll. Note that if $\mathrm{C}$ were considered a rider and would be struck down, the committee would have no incentive to open the gates and report $\mathrm{AB}$ to the full legislature, regardless of whether $\mathrm{AB}$ promised a substantial social benefit.

239. Legislative histories in many states are either non-existent or sparse. Richard A. Briffault, Beyond Congress: The Study of State and Local Legislatures, 7 N.Y.U. J. Legis. \& PuB. PoL'y 23, 25 (2003-2004). 
rather on the rest of the legislators who, on the floor of the legislature, voted for it. ${ }^{240}$ The key question is whether enough of those legislators would, if the bill's components had been voted on separately, withdraw their votes from a component such that it lacked majority support. Proof that several legislators sought to remove a provision of the bill through informal or other channels before voting for it could be evidence of riding.

Finally, courts could review voting records, political affiliation, and even poll data to hypothesize how legislators would vote on a truncated bill. ${ }^{241}$

If judges made clear that information of this nature would be relevant in single subject disputes, litigants would have a strong incentive to produce it. Indeed, judges should require parties bringing single subject cases to produce information on the legislative process that gave rise to the challenged act by adopting a presumption that, absent such information, no single subject violation has occurred. This approach would put the onus on the parties, and rightly so. Judges should be responsible for getting the rule right and for applying it properly, but they should not be obligated to uncover the factual inputs to their adjudicatory process. That duty belongs to the party bringing the case. This proposal runs contrary to contemporary single subject jurisprudence, under which litigants need only dream up a plausible formulation by which the components of a challenged act relate to more than one logical subject. ${ }^{242}$ Because multiple subjects are understood to constitute logrolling or riding, litigants need not inquire into the actual legislative activities that gave rise to the act. Consequently, the single subject rule is easy to invoke, and litigation is frequent.

In addition to putting more of the burden on litigants, judicial demands for information on the legislative history of challenged bills could change legislators' behavior. Fearing that popular provisions and logrolls would be mistaken for riders, legislators would have an incentive to keep better records.

240. Cf. Daniel B. Rodriguez \& Barry R. Weingast, The Positive Political Theory of Legislative History: New Perspectives on the 1964 Civil Rights Act and Its Interpretation, 151 U. PA. L. Rev. 1417, 1423 (2003) (arguing that courts should not look to the legislative history of a bill's drafters when interpreting the bill's meaning because those drafters are "typically ardent supporters who have strategic incentives to expand the meaning of the act ... and to minimize the impact of the changes necessary to gain the moderates' support").

241. For an example of a court using many of the tools identified to predict how the legislature would have voted on a particular bill, see Porten Sullivan Corp. v. State, 568 A.2d 1111, 1122 (Md. 1990).

242. This is particularly easy when litigants are bringing a case on other grounds and can simply tack on a single subject claim as an alternative line of attack. In the 210 single subject cases decided by courts in Nevada, South Carolina, and Utah, 173 of them (or eighty-two percent) involved at least one argument besides the single subject claim. See supra note 92 . 
Legislative histories could materialize in states where they previously were not kept, and they could explain clearly why, for example, a closed rule was used on a particular bill. Legislators could note if they bargained for a provision or were simply forced to accept it. The history would never be perfect, and sometimes legislators would have incentives to strategically distort the record. But any improvements would simplify the judicial task. Note, too, that clearer legislative histories - especially under a regime of legalized logrolling - would improve political transparency.

Beyond clarifying their legislative histories, legislators could insulate bills from a charge of riding by voting unanimously not to divide the question. ${ }^{243}$ According to Robert's Rules of Order,

When a motion relating to a certain subject contains several parts, each of which is capable of standing as a complete proposition if the others are removed, it can be divided into two or more propositions to be considered and voted on as distinct questions, by the assembly's adopting a motion to divide the question in a specified manner. ${ }^{244}$

Prior to voting on a bill, someone in the legislature could move that the bill at issue be divided. A unanimous vote not to divide the question would be clear evidence that the bill does not contain a rider; if it did, at least some of the rider's opponents would vote to divide the question. Of course, failure to achieve a unanimous vote should not lead to a presumption that riders are present. Even independently popular bills and beneficial logrolls can have harmful effects on a minority. That minority should not be permitted to sabotage a bill by disingenuously raising judicial scrutiny. This divide-thequestion technique could be used under open rules.

Even with the sorts of information outlined above, courts would make some mistakes and strike down logrolled or even popular provisions. However, there is no reason to suppose they would make more errors under the public choice framework than they would under the approach they currently employ. Moreover, the costs of judicial error would be mitigated to some extent if this framework deterred legislators from attaching riders in the first place. If judges made clear that they would vigorously review all

243. I am grateful to Barry Weingast and Matt Stephenson for a discussion on this point. 244. Henry M. Robert, Robert's Rules of Order Revised 24 (4th ed. 1915), available at http://www.rulesonline.com/ (last visited Mar. 6, 2006). Although Robert's Rules of Order is probably familiar to most readers, very few state legislatures use it to organize their proceedings. Most use Mason's Manual. See http://www.ncsl.org/programs/legman/about/masons.htm (last visited Aug. 22, 2006). It contains a similar divide-the-question provision. See Paul Mason, Mason's Manual of Legislative Procedure 227-32 (2000). 
challenged statutes for riders, the deterrent effect would increase. Indeed, legislators themselves - once they trusted that courts would not interfere with their logrolls - could use the threat of litigation to prevent colleagues from attaching riders. ${ }^{245}$

For all of the reasons presented, courts should adopt a presumption against riders and declare any bill containing one to be in violation of the single subject rule. This approach comports with the definition of a single subject provided in the previous section. A rider is neither popular on its face nor the result of legislative bargaining, so any bill containing a rider embraces more than one subject.

\section{Courts Must Enforce the Title Requirement}

Assuming they do not detect a rider, which would constitute a single subject violation and obviate the need for further analysis, courts adjudicating a single subject dispute must check for compliance with the title requirement. If the title gives general notice of all of the issues the bill touches upon, the title requirement is satisfied. If a bill's contents are not expressed in the title, it violates the single subject rule. This approach allows the definition of a single subject to be finalized. A bill can be said to embrace but one subject when all of its components command majority support due to their individual merits or legislative bargaining and the title gives notice of the bill's contents.

The rationale for enforcing the title requirement is the same under the public choice approach as under traditional single subject jurisprudence: to improve political transparency. As Part III argued, the quality of legislation will improve if legislators are aware of bills' contents. Clear titles will make it easier for legislators to understand what they are voting on. Of equal importance, citizens must be able to monitor their representatives to ensure that legislative activity is carried out with their best interests in mind. Clear titles will simplify the task of determining what issues legislators are voting for and against.

Reviewing the adequacy of bills' titles will necessarily involve some discretion. The line between minor, technical issues-inclusion of which would make titles inordinately long - and major issues that implicate citizens' interests is vague. However, the discretion under the public choice approach is no different from that in traditional single subject jurisprudence; the tests

245. Legislators sometimes use the single subject rule to challenge acts passed by their own chambers. See, e.g., DeWeese v. Weaver, 824 A.2d 364, 364 (Pa. Commw. Ct. 2003). 
are essentially the same. To focus the issue, courts should insist that litigants point to specific legislative provisions that failed to appear in the title and articulate the effects of that failure on their interests.

Under a regime of permissible logrolling, the title requirement could become increasingly important. Bills could expand in terms of length and the range of issues they address. Ideally, titles would become crisper, pithily expressing the contents of complicated acts. In practice, titles may simply grow beyond the point of usefulness. This implicates the broader relationship between logrolling and political transparency. As discussed in Part III, strict application of the single subject rule cuts against transparency by obscuring legislative bargains. Conversely, failure to limit the scope of acts could lead to bills so vast they are incomprehensible. Optimal application of the single subject rule would fall between these poles, allowing some measures to be combined so that tradeoffs can more easily be perceived but placing an upper limit on bills in the interest of transparency.

Unfortunately, optimal application is infeasible. Courts cannot design a rule that balances the gains and losses to political transparency from logrolling. In the abstract, such a rule would be too vague to provide legislators with a predictable restraint on their logrolling. In practice, precise application of such a rule would require more information than courts or litigants will ever possess. In lieu of an optimal rule, courts should adopt a presumption about the logrolling-transparency tradeoff that minimizes social costs. I propose they presume that logrolling always improves transparency. This presumption is based on two arguments.

First, most citizens do not monitor their representatives by reading bills and their titles. They get their political information from the media, interest groups, and politicians themselves. ${ }^{246}$ Even if a given bill and its title are too voluminous and complex to be comprehensible to average citizens, it is unlikely to confound intrepid reporters and interest groups whose job is to follow the political process. ${ }^{247}$ Second, a certain amount of logrolling within a given bill enhances transparency. Only when logrolling passes that threshold does transparency begin to suffer. The point at which logrolling

246. See generally Lupia \& McCuBbins, supra note 196.

247. Because citizens get much of their political information from specialized groups, one might question whether logrolling can actually enhance transparency - after all, such groups should be able to identify political tradeoffs even if they are splintered across multiple bills. Although this argument has some force, there is no reason to suppose that political watchdogs are perfect. Enhancing transparency would improve their performance. Moreover, the legislative process should be transparent enough that nonspecialist citizens can choose to monitor their representatives without relying entirely on watchdogs. 
confuses sophisticated observers who provide cues to citizens is probably close to the point where legislators elect to stop logrolling. Otherwise they risk confusing themselves and agreeing to a harmful exchange.

Judicious enforcement of the title requirement could improve the quality of laws and help citizens monitor their representatives. This would ensure that legislators act in their constituents' best interests, spreading the gains from political bargaining not just among politicians but among the public as well.

\section{Judges Should Think Twice Before Severing Bills}

Under the public choice approach to single subject disputes, violations of the rule could occur in two instances: when a bill contains a rider and when the contents of a bill are not adequately expressed in the title. If either of these violations is detected, the court must decide whether to strike down the entire bill or sever just the offending portion-i.e., the rider or the provisions that are not flagged in the title. At first blush, severing is an attractive option. When riders are present, they can be excised, and the popular and logrolled provisions of the bill can be left intact. This rewards legislators who enacted legislation through appropriate channels. It also protects expectations; individuals who are affected by a popular or logrolled provision will not have their behavior disrupted by removal of a rider. Similar arguments apply when the infirmity stems from an inadequate title. Provisions that were properly expressed in the title and that individuals have relied on appropriately will not be disturbed.

Notwithstanding these arguments, the case for severance is not clear cut. With respect to riders, severing them fails to provide legislators with an incentive not to engage in this behavior. Indeed, severing encourages legislators to attach riders: with any luck, they will go undetected and become law, and if they are detected, they will simply be removed and can be reattached to another bill. In either case, the popular provisions of the act will stand, and legislators responsible for riders will face limited political backlash. In contrast, if the presence of a rider leads to invalidation of an entire bill, legislators who attached the rider will pay a higher price. Other legislators, whose hard-fought political bargain was undone because of the rider, may be incensed and less likely to bargain with the culprits, and citizens may be 
enraged by the delay or failure to enact important legislation. ${ }^{248}$ Fear of these penalties could prevent riders from being attached in the first place.

With respect to title violations, severing may corrupt the political bargain. Many bills are logrolls and therefore the product of compromise. Lawmakers accept some provisions they dislike to secure passage of others they favor. To sever some components of such bills - those that are not flagged in the title - while upholding others - those that are flagged - would pervert the deal. Some legislators would receive their favored provisions without having to tolerate unfavorable measures that were severed. Other legislators would receive nothing in exchange for their support of the bill, their preferred provisions having been removed. In such situations, complete nullification may be superior to severance. This would unwind the legislative bargain but not pervert it. Lawmakers would be free to renegotiate a new version of the bill, having lost valuable time but not their votes.

With that said, severing in title cases does provide the sponsors of popular and logrolled provisions with a strong incentive to be sure that titles are complete. Legislators may include a provision in a bill but intentionally fail to mention it in the title. This could happen anytime the provision is acceptable to legislators but unacceptable to the public - perhaps because it favors narrow interests. If such provisions are severed, sponsoring legislators not only fail to receive their preferred provision, but they also, in the case of logrolls, are forced to accept unfavorable provisions that were part of the deal and that were properly noted in the title. This is worse than having the entire bill invalidated, which would cost the legislators their provision but not burden them with other measures they dislike. When severing is a possibility, legislators have an incentive to avoid this scenario by ensuring that their provisions are noted in bills' titles.

For all of these reasons, severing involves tradeoffs. A full examination of these tradeoffs is beyond the scope of this paper, but a few have been identified here that have not been discussed in the cases. The benefits of severing are the protection of sound legislation, expectations that have formed around it, and the creation of incentives to craft adequate titles for logrolled bills. The costs of severing are the failure to pressure legislators not to attach riders and the perversion of legislative compromises. Whether the benefits outweigh the costs in a given case is an empirical question.

248. A similar argument is articulated in Assoc. Builders \& Contractors v. Ventura, 610 N.W.2d 293, 310 (Minn. 2000) (Page, J., dissenting). 
As discussed, some courts are constitutionally required to sever offending provisions in single subject cases. ${ }^{249}$ This represents a presumption that, on average, the gains from severing - or at least from having a clear rule- outweigh the losses. Other courts have more flexibility. ${ }^{250}$ Courts could use this flexibility and the analysis presented here to tailor the decision to sever to individual cases. The following issue should be borne in mind: the benefits and costs of severing will vary with the age of the bill in question. Longstanding laws typically generate more reliance interests than new laws. Moreover, the ability to deter riders through nullification and inadequate titles through severance will probably decrease as guilty legislators retire; current legislators are unlikely to heed warnings from courts over legislation passed long before their time. Finally, corrupting political bargains - and therefore raising the costs of political bargaining going forward, as legislators insure against this risk - is less worrisome when some or all of the participants in the original bargain have left the statehouse.

\section{CONCLusion}

Despite 150 years of life and over 8,000 cases, the single subject rule remains a source of uncertainty and dissatisfaction. Judicial tests for enforcing the rule are abstract and can lead to inconsistent and unpredictable results. The root of the problem is the broad language of the rule itself and a series of misunderstandings about the legislative process. Given the ubiquity of single subject rules and the frequency with which they are litigated, judges, legislators, and citizens alike would benefit from a new approach to this area of law.

Public choice theory turns much of single subject jurisprudence on its head, offering compelling arguments in favor of logrolling and against riding, and demanding that more attention be paid to the comprehensibility of bills. More generally, it offers a framework for understanding legislative procedures, political bargaining, and the true merits of a single subject rule. This paper draws on public choice to develop a workable definition of a single subject. This definition in turn provides the basis for a systematic test for single subject violations. The test offers a coherent analytical framework for

249. See supra Part II.C.

250. See, e.g., Simpson v. Tobin, 367 N.W.2d 757, 768 (S.D. 1985) (suggesting that courts in South Dakota have the option to sever but are not required to do so). 
settling single subject disputes, and its application could improve the outcomes of the legislative process. 